\title{
APIFLAME v1.0: high-resolution fire emission model and application to the Euro-Mediterranean region
}

\author{
S. Turquety ${ }^{1}$, L. Menut ${ }^{2}$, B. Bessagnet ${ }^{3}$, A. Anav ${ }^{2, *}$, N. Viovy ${ }^{4}$, F. Maignan ${ }^{4}$, and M. Wooster ${ }^{5}$ \\ ${ }^{1}$ Laboratoire de Météorologie Dynamique, IPSL, Université Pierre et Marie Curie-Paris 6, UMR8539, 4 Place Jussieu, \\ 75252 Paris Cedex 05, France \\ ${ }^{2}$ Laboratoire de Météorologie Dynamique, IPSL, CNRS, Ecole Polytechnique, UMR8539, 91128 Palaiseau Cedex, France \\ ${ }^{3}$ Institut national de l'environnement industriel et des risques, Parc technologique ALATA, 60550 Verneuil en Halatte, France \\ ${ }^{4}$ Laboratoire des Sciences du Climat et de l'Environnement, IPSL, CEA-CNRS-UVSQ, UMR8212, Gif sur Yvette, France \\ ${ }^{5}$ King's College London, Environmental Monitoring and Modelling Group, Department of Geography, KCL, Strand, London, \\ WC2R 2LS, UK \\ *now at: University of Exeter, College of Engineering, Mathematics and Physical Sciences, Exeter EX4 4QF, UK
}

Correspondence to: S. Turquety (solene.turquety@1md.polytechnique.fr)

Received: 8 October 2013 - Published in Geosci. Model Dev. Discuss.: 6 November 2013

Revised: 19 February 2014 - Accepted: 24 February 2014 - Published: 11 April 2014

\begin{abstract}
This paper describes a new model for the calculation of daily, high-resolution (up to $1 \mathrm{~km}$ ) fire emissions, developed in the framework of the APIFLAME (Analysis and Prediction of the Impact of Fires on Air quality ModEling) project. The methodology relies on the classical approach, multiplying the burned area by the fuel load consumed and the emission factors specific to the vegetation burned. Emissions can be calculated on any user-specified domain, horizontal grid, and list of trace gases and aerosols, providing input information on the burned area (location, extent), and emission factors of the targeted species are available. The applicability to high spatial resolutions and the flexibility to different input data (including vegetation classifications) and domains are the main strength of the proposed algorithm. The modification of the default values and databases proposed does not require any change in the core of the model.

The code may be used for the calculation of global or regional inventories. However, it has been developed and tested more specifically for Europe and the Mediterranean area. A regional analysis of fire activity and the resulting emissions in this region is provided. The burning season extends from June to October in most regions, with generally small but frequent fires in eastern Europe, western Russia, Ukraine and Turkey, and large events in the Mediterranean area. The resulting emissions represent a significant fraction of the total yearly emissions (on average amounting to
\end{abstract}

$\sim 30 \%$ of anthropogenic emissions for $\mathrm{PM}_{2.5}, \sim 20 \%$ for $\mathrm{CO})$. The uncertainty regarding the daily carbon emissions is estimated at $\sim 100 \%$ based on an ensemble analysis. Considering the large uncertainties regarding emission factors, the potential error on the emissions for the various pollutants is even larger. Comparisons with other widely used emission inventories show good correlations but discrepancies of a factor of 2-4 in the amplitude of the emissions, our results being generally on the higher end.

\section{Introduction}

Fires are a major source of trace gases and aerosols, critically perturbing atmospheric composition (Seiler and Crutzen, 1980; Andreae and Merlet, 2001), with various impacts on the atmospheric environment (Turquety, 2013, and references therein). The relatively long lifetime of several key emitted species allows long-range transport of the fire plumes, which thus may have a significant impact at regional to hemispheric scales (e.g., Langmann et al., 2009; Jaffe and Wigder, 2012) and control interannual variability for various species (e.g., Spracklen et al., 2007; Szopa et al., 2007; Jaffe et al., 2008). The dense fire plumes may in turn influence the radiative budget, and thus climate and mesoscale meteorology (Koren et al., 2004; Tosca et al., 2013), as well as 
cloud microphysics (Andreae et al., 2004; Grell et al., 2011). However, the most direct impact of fire emissions remains the degradation of local and regional air quality. In order to understand these impacts and the associated physical and chemical processes, accurate biomass burning emissions need to be integrated into chemistry transport models (CTMs). In this publication, we present a new model for the calculation of daily high-resolution emissions of trace gases and aerosols, which was developed more specifically to meet the needs of air quality monitoring. For this purpose, it was designed to allow calculations at high spatial and temporal resolution and to change the domain of interest and the input data sets easily, depending on the region studied. The emission model may be used for any region of the globe but particular emphasis is placed here on the Euro-Mediterranean region. We provide a first regional analysis of fire activity and the related emissions.

Unlike in some tropical or boreal regions, fires in Europe are not the dominant source of pollution in terms of total mass emitted. However, European fires can be an important source of pollutants during the fire season (typically June to October) and may cause extreme pollution events during periods of high fire activity (usually in the summer). According to the monitoring and yearly reports from the European Forest Fire Information System (EFFIS) operated by the Joint Research Center (JRC), the countries most affected by fires are Spain, Italy, Portugal, Greece and France. Almost $85 \%$ of the total burned area is located in the Mediterranean area. However, fires in eastern Europe and western Russia are also frequent during spring and summer (Stohl et al., 2007; Amiridis et al., 2010). Although the number of fires has decreased in the past decades due to fire suppression policies, the yearly area burned has remained constant due to a constant number of large fire events. San-MiguelAyanz et al. (2013) estimate that about $2 \%$ of "mega-fires" contribute to $80 \%$ of the total area burned. These events correspond to clusters of fires that burn simultaneously and propagate rapidly due to critical meteorological conditions - hot and dry conditions with strong winds (Pereira et al., 2005) - and are thus particularly difficult to control. During large wildfire events, such as the Portuguese fires in 2003, the Greek fires in 2007 or the Russian fires in 2010, contributions from fires emissions were comparable to anthropogenic activities but concentrated in time and space (Hodzic et al., 2007; Turquety et al., 2009; Hodnebrog et al., 2012; Konovalov et al., 2011; R'Honi et al., 2013). It is critical to evaluate their impact, as the large fires often occur close to densely populated areas, and during hot and dry summers, in conditions already favorable for the development of photochemical pollution episodes. Air quality assessments report compliance with limit concentrations for a series of pollutants in terms of a number of exceedances of daily and yearly limit values. In the 2008/50/EC (EC, 2008) directive of the European Commission on ambient air quality and cleaner air for Europe, $\mathrm{PM}_{10}$ (particulate matter with diameters less than
$10 \mu \mathrm{m})$ exceedances that have a natural origin can be substracted from the total number of exceedances that have to be reported. Forest fires can fall in this category: they can explain significant exceedances that are not attributable to monitored anthropogenic emissions.

For air quality monitoring applications, knowledge of the emitted mass for the main pollutants has to be provided at a high horizontal resolution in order to simulate the plume transport pathways (correct location and spread) accurately, and at a high temporal resolution to capture the large variability of fire activity. Calculating the emissions requires knowledge of the quantity and type of vegetation burned, but also of the type of fire (smoldering vs. flaming). However, except for the study of specific, fully monitored fires, this information is often missing and needs to be estimated.

The availability of satellite-based fire monitoring since the mid-1990s, of active fires and the associated area burned (e.g., Giglio et al., 2006, 2010) has allowed the development of more and more realistic inventories of the resulting emissions (Hoelzemann et al., 2004; Mieville et al., 2010; van der Werf et al., 2006, 2010; Wiedinmyer et al., 2011; Urbanski et al., 2011). Most inventories are based on the initial formulation of Seiler and Crutzen (1980), which derives emissions from the initial burned area. Recent studies have used an alternative approach, relying on the instantaneous fire radiative power (FRP), a measure of the rate of radiant energy emission from the fire, to derive directly the amount of fuel burned (Freeborn et al., 2008). This approach is mainly used for operational monitoring purposes (Kaiser et al., 2012; Sofiev et al., 2009).

In spite of the increasing number of satellite observations of fire activity, uncertainties regarding biomass burning emissions remain large. They are associated with the evaluation of the burned area, the corresponding fire characteristics (vegetation burned and fuel load consumed) and emission factors (Langmann et al., 2009). Providing uncertainty assessment is particularly difficult, mostly due to the lack of references from in situ measurements. Intercomparison exercises have shown large discrepancies in burned area estimates (Hyer and Reid, 2009; Giglio et al., 2010) or resulting emissions (Stroppiana et al., 2010). In their intercomparison, Stroppiana et al. (2010) find that European biomass burning emissions of carbon monoxide (CO) for the year 2003 range from 1.6 to $87.8 \mathrm{Tg}$ depending on the methodology and area burned product used. van der Werf et al. (2010) used a Monte Carlo approach to evaluate the impact of uncertainties in each step of the calculation of the resulting emissions. They estimate an uncertainty of $\sim 20 \%$ in the total yearly carbon emissions. Using the same method, Urbanski et al. (2011) estimate the uncertainty of western United States emissions at $<50 \%$ for CO, increasing to $<133 \%$ for daily emissions at $10 \mathrm{~km}$ resolution for $50 \%$ of the total CO emissions. Uncertainties regarding daily emissions are generally estimated to be of a factor of 2 (Wiedinmyer et al., 2011). 
In this publication, we provide a full description of a new model for the calculation of emissions at high resolution, developed in the framework of the APIFLAME (Analysis and Prediction of the Impact of Fires on Air quality ModEling) project. The approach chosen is based on the Seiler and Crutzen (1980) classical approach. A general representation of the model is provided in Fig. 1. The APIFLAME emissions' model was designed to allow calculation at high temporal and spatial resolution, but also flexibility of the key fire characteristics. The input information required is the location of fires, the vegetation map for the region considered, and vegetation model simulations for the biomass density. The model then allows the calculation of emissions of any species for which emission factors are provided, as well as their conversion to gridded emission fluxes suitable for use in chemistry-transport models.

The input data used are first described. These include the vegetation maps and the ORCHIDEE global dynamic vegetation model (Krinner et al., 2005; Maignan et al., 2011) used for biomass density estimation, described in Sect. 2, as well as the satellite observations used for fire location, described in Sect. 3. An overview of fire characteristics over the Euro-Mediterranean region, our region of application, is then presented for the 2003-2012 time period, based on the input satellite observations (Sect. 4). Each part of the emissions' model is described in Sect. 5. The emissions obtained in the Euro-Mediterranean region for key pollutants are presented in Sect. 6, and compared to estimates from other widely used inventories. A more precise evaluation at daily temporal resolution is done for the case study of the summer 2007, which was among the worst fire seasons of the past decades in Europe, and is discussed in Sect. 7. An analysis of the related uncertainty is undertaken using two complementary approaches: a comparison with other inventories, and the calculation of an ensemble of results obtained when changing the input information for burned areas and fuel load. Finally, the code structure is presented in Sect. 8 .

\section{Vegetation susceptible to burning}

Fire behavior and the amount of trace gases and aerosols emitted by a given fire strongly depend on the burned vegetation (type and density of fuel). For specific areas and specific fires, this information may be provided by forestry services. However, for large regions, it is necessary to rely on more systematic and self-consistent landuse databases and modeling of the carbon cycle and vegetation dynamics (e.g., Sitch et al., 2003; Krinner et al., 2005; Li et al., 2012). This section briefly describes the approach used in this work.

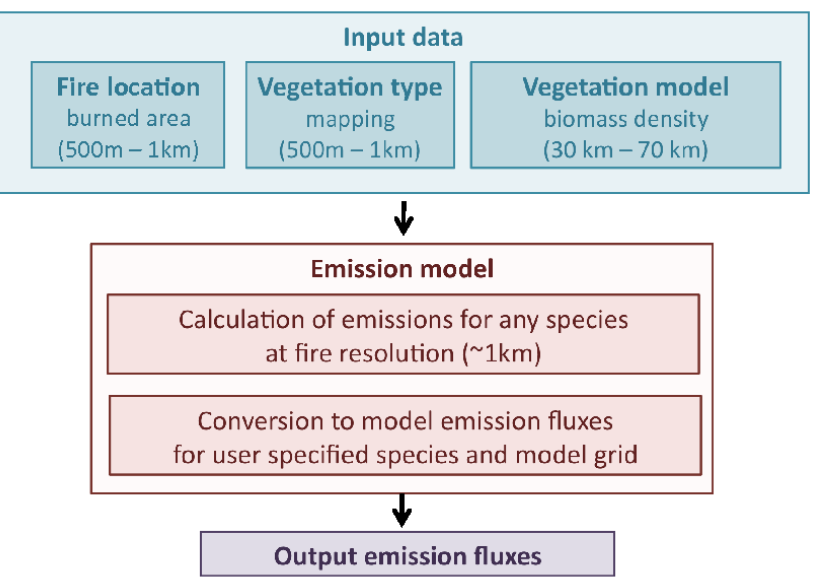

Fig. 1. Schematic representation of the general structure of the emissions' calculation with the APIFLAME model.

\subsection{Vegetation type databases}

Several land cover databases are available. In this study, the main constraint was to use a high-resolution land cover map to attribute as precisely as possible the type of vegetation burned for Europe.

For Europe, we have chosen to use the satellite-based CORINE (coordination of information on the environment) land cover database (CLC) (EEA, 2007). It provides the land cover class at a resolution of $250 \mathrm{~m}$. The 2006 database is used when available, the 2000 database otherwise (Greece for instance). The 44 original classes have been merged into 13 vegetation classes, listed in Table 1 . Artificial and sparsely vegetated classes are also included but are not allowed to burn (assume false detection). For convenience, the CLC database has been regridded to a $1 \mathrm{~km} \times 1 \mathrm{~km}$ grid. The fraction of each vegetation type within each grid cell is then used for landuse attribution.

Outside of the region covered by this database, we use the yearly percent vegetation cover from the MODIS (Moderate Resolution Imaging Spectroradiometer) satellite instrument, and the MCD12Q1 collection 5 land cover type product (referred to as MODIS MCD12 in the following) (Friedl et al., 2010). The year 2006 is used here, but the code can run with a year-specific database. Among the provided vegetation types, we arbitrarily chose to use the IGPB (International Geosphere-Biosphere Program) land cover classification.

The fraction of vegetation cover, represented on a $0.1^{\circ} \times$ $0.1^{\circ}$ grid, is shown in Fig. 2 for both CLC and MODIS MCD12 databases. While the general patterns are consistent for all databases (dominance of forest, especially north of $50^{\circ} \mathrm{N}$, croplands and grasslands in the mid-latitudes and of shrublands in the Mediterranean area), there are significant differences in the relative fractions and distributions in some regions. For example, the distribution of croplands is significantly different. 
Table 1. Land cover categories in the CORINE land cover, and corresponding general ecozone and ORCHIDEE PFT. The applied weight is indicated in parentheses if different than 1.

\begin{tabular}{|c|c|c|c|}
\hline Class & Vegetation type & Emission factor type & ORCHIDEE PFT \\
\hline 1 & Arable land & Crop residue $(25 \%)$ & Agriculture $(25 \%)$ \\
\hline 2 & Permanent crop & Crop residue & Agriculture \\
\hline 3 & Pasture & Pasture $(25 \%)$, savanna $(75 \%)$ & Grass \\
\hline 4 & Mixed cropland and other vegetation & Crop residue $(50 \%)$, savanna $(50 \%)$ & Agriculture $(50 \%)$, grass $(50 \%)$ \\
\hline 5 & Mixed cropland and forest & Crop residue $(50 \%)$, forest $(50 \%)$ & Agriculture $(50 \%)$, forest \\
\hline 6 & Forest: broad-leaved & Forest & Forest \\
\hline 7 & Forest: coniferous & Forest & Forest \\
\hline 8 & Forest: mixed & Forest & Forest \\
\hline 9 & Natural grassland & Savanna & Grass \\
\hline 10 & Moors and heathland & Savanna $(70 \%)$, forest $(20 \%)$, peat $(10 \%)$ & Forest, grass \\
\hline 11 & Sclerophyllous vegetation & Chaparral & Forest, grass \\
\hline 12 & Transitional woodland/shrubland & Savanna $(50 \%)$, forest $(50 \%)$ & Forest, grass \\
\hline 13 & Peat bogs & Peatland & Forest, grass \\
\hline
\end{tabular}

However, since vegetation classes are not always the same, exact comparisons can be difficult. For example, pasture in the CLC is attributed in these maps to the grassland type and natural grasslands to savanna. In the MODIS/IGBP classification, both savanna and grassland are provided. Grassland corresponds to herbaceous areas with tree and shrub cover lower than $10 \%$. In the savanna class, forest can be 10-30\% of the vegetation cover (forest canopy $\geq 2 \mathrm{~m}$ ). Natural grassland in CLC correspond to areas with a least $75 \%$ herbaceous vegetation. There is thus uncertainty in the exact correspondence between the different classifications.

In addition to these Level 3 (L3) observations (corresponding to a climatology of Level 2 retrievals from Level 1 radiance measurements), the USGS (US Geological Survey) land use classification at $1 \mathrm{~km} \times 1 \mathrm{~km}$ can also be used in the emissions' model. The sensitivity to using either one of these distributions in the calculation of the emissions is tested in Sect. 7.2.

Note that neither the MCD12 nor the USGS classification includes peat bogs. For these databases, wetlands are used as a proxy for peatlands in the calculation of the emissions. For a more precise analysis of the impact of peat burning in western Russia, the mires vegetation type (also classified in the wetlands) from the Eurasian mapping of Bartalev et al. (2003) was used.

The MODIS vegetation continuous field (VCF) data at $500 \mathrm{~m}$ resolution (MOD44B L3 data set) (Hansen et al., 2003), providing the fraction of pixels covered by vegetation, are also used for area burned processing.

\subsection{Biomass density}

To estimate the biomass density in an area affected by fires, simulations by the ORCHIDEE global dynamic vegetation model (Krinner et al., 2005; Maignan et al., 2011) have been used. ORCHIDEE simulates the interactions between surface and atmosphere, the continental carbon cycle and the longterm evolution of vegetation. It consists of three modules: the SECHIBA model describes the hydrology; the STOMATE model simulates the daily phenology and continental carbon cycle, and the LPJ model is used for the long-term vegetation dynamics. Two ORCHIDEE simulations are used in this study: a global simulation at $70 \mathrm{~km}$ and a regional simulation at $30 \mathrm{~km}$ for the Euro-Mediterranean area (Anav et al., 2010).

The global simulation, detailed in Maignan et al. (2011), is provided to allow full flexibility of the methodology in terms of area of interest, although the inventory is primarily developed for Europe. It is based on the ORCHIDEE 1.8.2 release, with an improved phenological model for crops. The simulation is forced by ECMWF ERA-Interim meteorological fields (Berrisford et al., 2009), over the 1989-2008 period, starting from an equilibrium state for all carbon reservoirs. The soil map, giving fractions of sand, silt and clay, is derived from Zobler (1986).

The regional simulation was based on a $0.25^{\circ} \times 0.25^{\circ}$ climate forcing by the REMO regional climate model (Jacob and Podzun, 1997), provided in the framework of the CEXTREM European project. The simulation is started with a spinup to a neutral net $\mathrm{CO}_{2}$ exchange in 1901 and then run using changing climate and $\mathrm{CO}_{2}$ but with fixed land cover. The soil map is derived from the European 1: 1000000 soil database (Panagos, 2006).

Like in other dynamic global vegetation models, vegetation in ORCHIDEE is represented as a set of plant functional types (PFTs). Each PFT is represented in the model as a unique set of parameterization and parameters. 13 different PFTs are defined in ORCHIDEE mainly splitting vegetation between grass and trees. For trees there is a distinction between phenology (evergreen or deciduous), leaf form (needleleaf or broadleaf), and climate (boreal, temperate and tropical). For grass there is a distinction between natural grassland and crops and a distinction between C3 and C4 

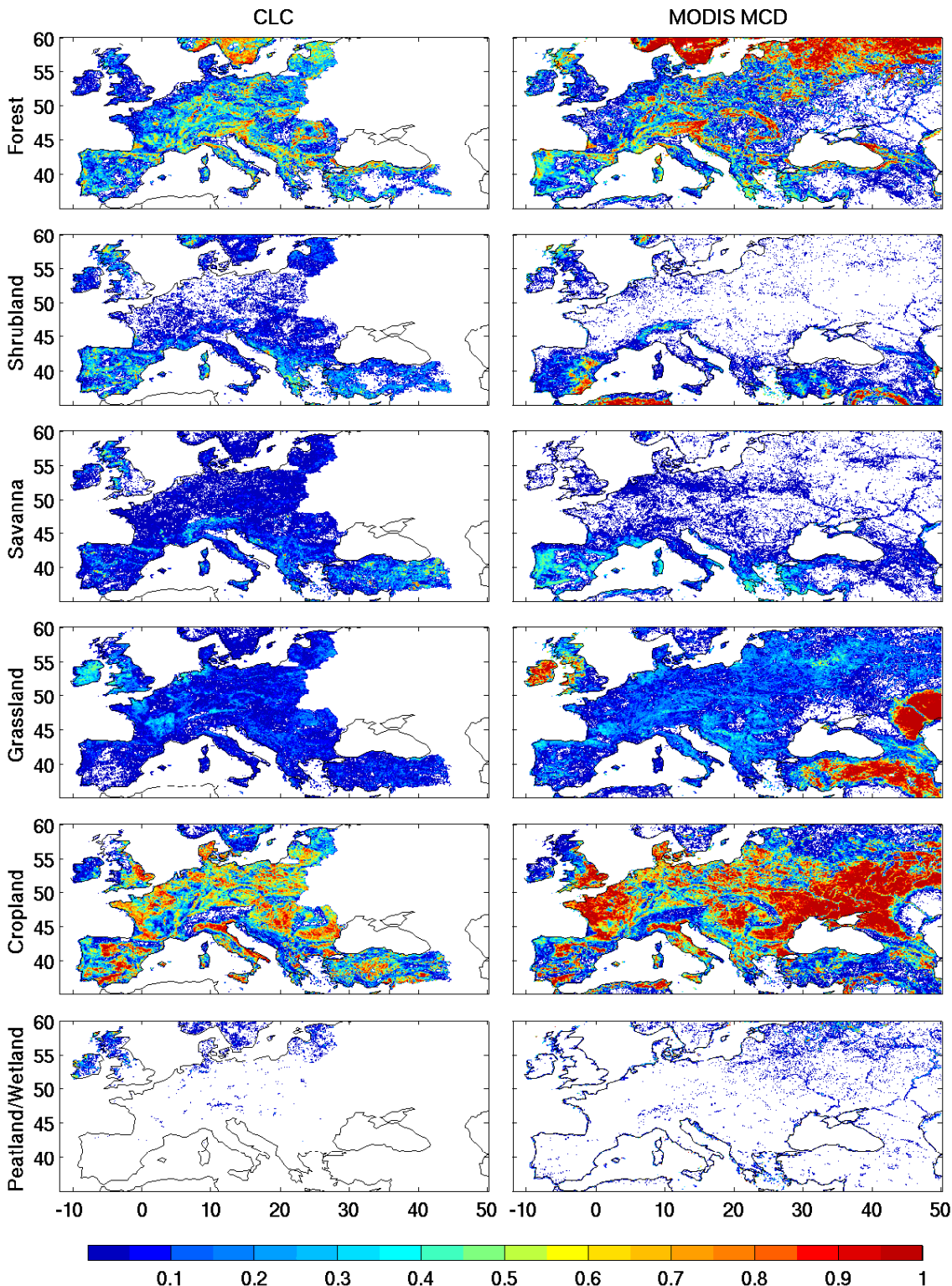

Fig. 2. Fraction of vegetation cover for grouped vegetation types and the CLC and MODIS MCD12 databases (reference year 2006), averaged on a $0.1^{\circ} \times 0.1^{\circ}$ grid. For CLC, savanna corresponds to natural grassland and grassland to pasture, for MODIS MCD12, specific vegetation types are assigned to shrubland, savanna and grassland. White areas to the east of the domain in the CLC maps correspond to unavailable data.

pathways for photosynthesis. The fraction of each PFT is either calculated (thus variable in time) by the model depending on the climatic input forcing or prescribed. In order to avoid having an odd model initialization and thus unrealistic vegetation cover, for each grid cell the fraction of each PFT is prescribed using a vegetation map as input (Krinner et al., 2005). For Europe this PFT map is derived from CORINE land cover (CLC) map.

According to the vegetation type associated with a specific fire (Sect. 2.1), a corresponding PFT is attributed. Therefore, a matrix of correspondence between vegetation class and PFT, described in Table 1, is used. The biomass density for a specific fire then corresponds to the sum of the biomass densities of all contributing PFTs in the ORCHIDEE grid cell where the fire is located (nearest neighbor approach). For example, if a fire is found to be burning in "Mixed cropland and forest", the biomass density will be evaluated as the sum of the biomass densities in PFT "Agriculture" and "Forest". Since agricultural fires are often less intense and may not burn the full area, the contribution from this PFT is divided by two. All forest types are merged together in order to avoid uncertainties in the forest type classification, but attribution 
to either tropical, temperate and boreal forest is used for the emission factors attribution (Sect. 5.2).

Since ORCHIDEE simulations were performed using the CLC vegetation classification as a reference, a good consistency is expected between dominant PFTs in a given ORCHIDEE grid cell and vegetation type attribution. For example, the fraction of forest in the PFT distribution of the global ORCHIDEE simulation over the Euro-Mediterranean region is equal to $17 \%$, which is close to the $16 \%$ obtained for forest vegetation types in CLC, and the $19 \%$ in MCD12.

Among the carbon pools included in the model, we assume that four classes are subject to burning: litter, wood, leaves, and roots. Litter includes all dead plant material that is not already decomposed (leaves and all dead wood material). The wood pool corresponds only to wood of living trees (bole and branches). There is no specific representation of shrubs. They are considered to be "small trees", so that, like for trees, the above-ground biomass of woody shrubs is split into wood and leaves. The wood, leaves and roots carbon pools are the largest contributions for forest PFT (Hoelzemann et al., 2004; Li et al., 2012). Wood contributes a very small fraction for both grasslands and croplands. The seasonal cycle in the ORCHIDEE simulations varies depending on the pool: maximum carbon content is reached in spring for wood, summer for leaves and roots and winter for litter. It is based on the balance between net productivity that is allocated to the different pools based on dynamic allocation rules, the turnover time of the biomass, and the decomposition rates (Krinner et al., 2005). The turnover is separated between a seasonal turnover (e.g., leaves, fine roots) and a long-term mortality of wood that in these simulations is considered for each year to be a constant fraction of the total biomass (depending on the PFT). A slight increase in the vegetation biomass during the last decades is associated with the response to increasing $\mathrm{CO}_{2}$, accounted for in the simulations (Sitch et al., 2013).

Ground layer burning other than roots is not considered in the present version of the inventory, but it will be included in a subsequent version to allow accurate application of the algorithm to boreal regions, where ground layer burning is critical (e.g., Soja et al., 2004). There is no specific PFT for peatlands, so when a fire is detected in this vegetation type, the biomass density is derived from the densities of forest and grassland PFTs. Since this does not include the ground layer, the fuel load may be strongly underestimated. Therefore, fuel consumption values from the literature can be used for this type of fire, as detailed in Sect. 5.1.

The horizontal resolution of biomass density is coarser (30 or $70 \mathrm{~km}$ ) than that of fire detection and vegetation mapping (500 $\mathrm{m}$ for the MODIS burned area and vegetation map, $1 \mathrm{~km}$ for the CLC vegetation map), but a higher resolution vegetation mapping is used for the choice of PFT.

\section{Remote sensing observations of fire activity}

Reports of fire locations, size and durations are often available from forestry agencies and fire fighter's reports. However, for regional applications, only satellite remote sensing can provide a complete and self-consistent picture of fire activity, with location and temporal variability. The burned areas derived directly from satellite are now showing good performance (Giglio et al., 2010), although uncertainties inherent to satellite observations remain (Hyer and Reid, 2009).

When detailed reports are available for the region analyzed, combining reports with precise locations from satellite can provide more realistic quantification of areas burned (e.g., Turquety et al., 2007). For time periods with no satellite observations available, statistical analysis of fire reports and tree-ring reconstructions have been used to analyze fire history (Mouillot and Field, 2006).

The emissions' model presented here may be used with any burned area database, provided the date of burning, location and corresponding area is known. For the application to Europe and the Mediterranean area, we have chosen to use satellite remote-sensing observations. The fire characteristics will be described in terms of both active fires and burned areas. Both products are briefly described in this section. However, the emissions are calculated based solely on the area burned detection. No combination of active fires and burned area is undertaken in this study.

\subsection{Active fires}

There are several satellite sensors allowing the monitoring of active fires based on thermal anomaly measurements ("hotspots") (Roy et al., 2013). Here, we have focused on two complementary observations.

The active fire products from the Moderate Resolution Imaging Spectroradiometer (MODIS), carried on board the polar orbiting satellite platforms Terra since 2000 and Aqua since 2003, have been used. More specifically, we used the MOD14 product (Giglio et al., 2006) at a $1 \mathrm{~km} \times 1 \mathrm{~km}$ resolution, which provided both the location of the thermal anomalies, and the associated fire radiative power (FRP) observations. The FRP provides direct information on the fire radiant heat energy and thus provides a measure of fire intensity that has been linked to the fire fuel consumption rate (Wooster et al., 2005; Freeborn et al., 2008). With a swath of $2330 \mathrm{~km}$ across the nadir, MODIS has a revisit cycle of about 1 to 2 days. Its presence on board two satellites further increases its coverage. In our analysis, only observations with a nominal to high confidence level (quality index greater than 7 on a scale from 0 to 9 ) are used. In addition to bad detections, this excludes low confidence fires as well as non-fire thermal anomalies (e.g., volcanoes).

The SEVIRI/MSG geostationary observations also allow a monitoring of thermal anomalies and FRP (Wooster et al., 2005; Roberts et al., 2005), as well as their evolution during 
the course of a day with measurements every 15 min. However, the pixel size of $3 \mathrm{~km}$ is coarser than for MODIS, resulting in a higher detection limit (small fires may be missed). These fire detection products are thus complementary and are here used in conjunction.

These thermal radiation measurements are only available under cloud-free conditions, which may introduce uncertainties in the temporal variations of fires. However, they are the only measurements available in near-real time and are thus used in many operational monitoring systems or emissions inventories (e.g., Sofiev et al., 2009; Wiedinmyer et al., 2011; Kaiser et al., 2012).

\subsection{Burned area}

Several recent satellite products provide estimates of the burned areas based on burned scars. In particular, two products based on MODIS satellite observations are increasingly used in the community: the MODIS MCD45 product (Roy et al., 2008), and the MODIS MCD64 product (Giglio et al., 2010). According to the intercomparison in Giglio et al. (2010), the variability of area burned is consistent in both products, but MCD45 tends to be higher. Both data sets provide the date of burning within $500 \mathrm{~m} \times 500 \mathrm{~m}$ grid cells, and an associated level of confidence. Only the highest quality data are included in this analysis (quality assessment index equal to 4 on a scale from 1 to 4 ). An inherent uncertainty is associated with the satellite pixel size: within the $500 \mathrm{~m} \times 500 \mathrm{~m}$ areas, heterogeneities can be large, implying uncertainty regarding the actual area burned, and regarding the associated vegetation.

Following the approach of Wiedinmyer et al. (2011), area burned maps are derived by combining the burned pixel detection with the MODIS VCF product (Hansen et al., 2003) in order to determine the fraction of vegetation in each cell. Only that fraction is assumed to have burned (the bare fraction is not burned). In this paper, the different burned area data sets are referred to as MCD45 and MCD64, but correspond to the scaled area burned values. Both MCD45 and MCD64 products have been used in the emission model for uncertainty analysis (Sect. 3). In Sect. 4, the variability of the area burned in Europe is analyzed based on the scaled MCD64 data.

\subsection{False detections}

Even using the highest confidence observations in the available data sets, some false detections remain, especially for the active fires. This often corresponds to power plants, gas flares or other industrial activities, or active volcanoes. Previous analyses have used maps of persistent hotspots or high FRP to remove spurious detections, for example $\mathrm{Mu}$ et al. (2011) for the GFEDv3 inventory or Kaiser et al. (2012) for the GFASv1 inventory, both using masks at $0.5^{\circ}$ resolution. In this work, we also developed a procedure including
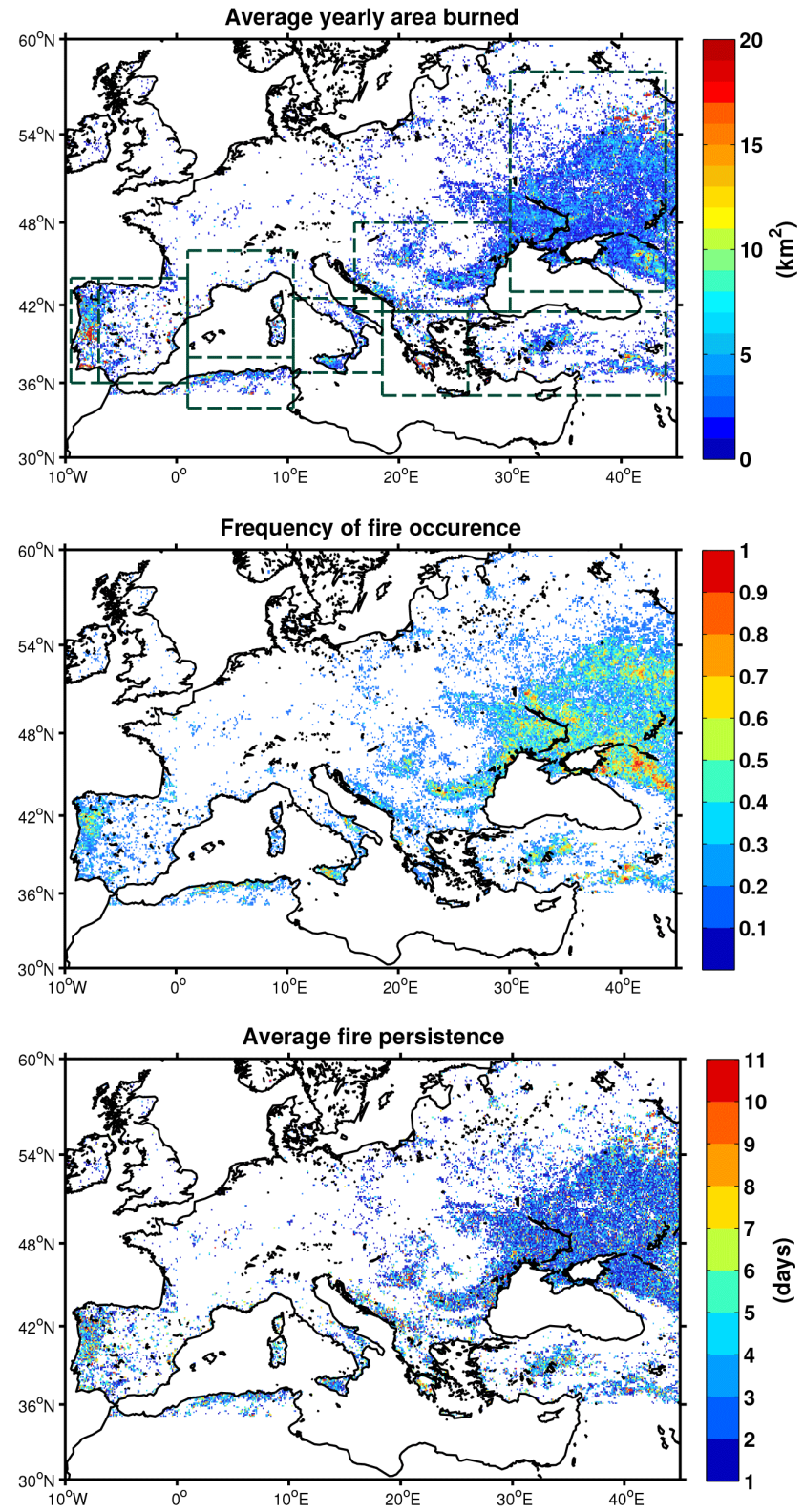

Fig. 3. Averaged total yearly burned area on a $0.1^{\circ} \times 0.1^{\circ}$ grid according to the MODIS MCD64 product for the 2003-2012 time period, corresponding frequency of fire occurrence, and average duration of the fire events within each grid cell. Regions used for the statistical analysis are indicated in the top panel.

successive tests to avoid computing emissions at these locations. False detection is assumed if:

- the fire is detected in an urban or a sparsely vegetated class;

- the urbanized fraction in the corresponding land cover ( $1 \mathrm{~km}$ resolution) is larger than $20 \%$; 
Table 2. Comparison of total yearly burned area $\left(\mathrm{km}^{2}\right)$ by country from the EFFIS/JRC reports and this study (derived from MODIS MCD64).

\begin{tabular}{|c|c|c|c|c|c|c|c|c|c|c|c|c|}
\hline Country & Database & 2003 & 2004 & 2005 & 2006 & 2007 & 2008 & 2009 & 2010 & 2011 & Correlation & Bias* $(\%)$ \\
\hline \multirow[t]{2}{*}{ Portugal } & EFFIS & 4257 & 1295 & 3383 & 755 & 314 & 172 & 874 & 1331 & 738 & 0.99 & -24 \\
\hline & MCD64 & 4504 & 964 & 3330 & 863 & 138 & 57 & 550 & 1270 & 402 & & \\
\hline \multirow[t]{2}{*}{ Spain } & EFFIS & 1482 & 1342 & 1887 & 1488 & 820 & 503 & 1108 & 548 & 845 & 0.95 & -32 \\
\hline & MCD64 & 1541 & 1212 & 1442 & 1294 & 365 & 189 & 697 & 232 & 541 & & \\
\hline \multirow[t]{2}{*}{ France } & EFFIS & 733 & 137 & 221 & 78 & 86 & 60 & 170 & 103 & 96 & 0.97 & -20 \\
\hline & MCD64 & 584 & 83 & 163 & 36 & 30 & 119 & 118 & 141 & 23 & & \\
\hline \multirow[t]{2}{*}{ Italy } & EFFIS & 918 & 602 & 476 & 399 & 2277 & 663 & 733 & 465 & 720 & 0.79 & -26 \\
\hline & MCD64 & 678 & 845 & 210 & 105 & 1293 & 813 & 391 & 464 & 331 & & \\
\hline \multirow[t]{2}{*}{ Greece } & EFFIS & 35 & 103 & 64 & 127 & 2257 & 292 & 353 & 90 & 291 & 0.99 & 75 \\
\hline & MCD64 & 65 & 220 & 96 & 272 & 3027 & 713 & 323 & 159 & 495 & & \\
\hline \multirow{2}{*}{$\begin{array}{l}\text { Republic } \\
\text { of Moldova }\end{array}$} & EFFIS & $\mathrm{NaN}$ & N/A & N/A & N/A & 327 & 59 & 13 & 7 & 173 & 0.92 & -3 \\
\hline & MCD64 & 5 & 14 & 17 & 12 & 334 & 65 & 0 & 10 & 62 & & \\
\hline \multirow[t]{2}{*}{ Bulgaria } & EFFIS & 50 & 11 & 15 & 35 & 430 & 53 & 23 & 65 & 69 & 0.66 & 887 \\
\hline & MCD64 & 228 & 442 & 149 & 638 & 768 & 351 & 52 & 193 & 239 & & \\
\hline \multirow[t]{2}{*}{ Romania } & EFFIS & 8 & 1 & 2 & 9 & 25 & 4 & 10 & 2 & 22 & -0.1 & $20 \times 10^{3}$ \\
\hline & MCD64 & 157 & 462 & 313 & 752 & 688 & 2546 & 261 & 755 & 695 & & \\
\hline \multirow[t]{2}{*}{ Turkey } & EFFIS & 66 & 49 & 28 & 78 & 117 & 297 & 47 & 33 & 36 & -0.35 & $5 \times 10^{3}$ \\
\hline & MCD64 & 967 & 1347 & 1271 & 1604 & 1393 & 1193 & 6787 & 3528 & 4732 & & \\
\hline
\end{tabular}

* $\left(A_{\mathrm{M}}-A_{\mathrm{E}}\right) / A_{\mathrm{E}} \times 100$, with $A_{\mathrm{E}}$ and $A_{\mathrm{M}}$ the total yearly burned area for one specific country reported by EFFIS and observed by MODIS, respectively.

- the fire location is within $1 \mathrm{~km}$ of an industrial facility using the European Pollutant Release and Transfer Register (e-PRTR http://prtr.ec.europa.eu/) database;

- the fire location is within $1 \mathrm{~km}$ of an active volcano;

- the statistical analysis of MODIS active fires (at $10 \mathrm{~km}$ resolution) for the past $10 \mathrm{yr}$ shows an unrealistically high frequency of fires throughout the year (burning $\geq 40 \%$ of the days).

These tests are applied to all satellite-based fire data sets used (burned areas and active fires). This may result in a slight underestimate in the case of fires close to inhabited regions.

\section{Overview of fire activity in the Euro-Mediterranean region}

Variability of the fire activity is the main driver for variability in fire emissions, even if the type of vegetation burned is also a key factor in understanding the amount of trace gases and aerosols emitted. Therefore, spatial and temporal variations are first analyzed, using the observations of area burned (MODIS MCD64 product) and active fires (MODIS MOD14 product) for the 2003-2012 time period, averaged over a $0.1^{\circ} \times 0.1^{\circ}$ grid.

\subsection{Seasonal and interannual variability}

Figure 3 shows the averaged total yearly area burned (for each grid cell: the total area burned during the period is divided by the number of years with fires detected), as well as the probability of detecting at least one fire during the year within each grid cell. The main regions affected by vegetation fires are southern countries (the Iberian Peninsula and the Mediterranean area) and eastern countries (eastern Europe, Russia, Ukraine). Large burned areas are mainly observed in the southern countries, but are less frequent than the small fires occurring in the eastern part of the region. Large events (large burned areas, but with low frequency) are also observed in northwestern Russia.

The total yearly burned areas by country have been compared to the European Fire Database from the EFFIS/JRC, which reports the forest fire data provided each year by individual countries (Schmuck et al., 2013). Table 2 summarizes results for countries with the most significant burning. For the case of Russia, the selected region for this analysis does not include the whole country. Since EFFIS reports total numbers, Russia has not been included in this comparison. For the southern countries, Portugal, Spain, France, Italy, the republic of Moldova, and Greece, the agreement between the reports and the MODIS MCD64 observations is good, with correlations larger than 0.92 . We note a tendency to 

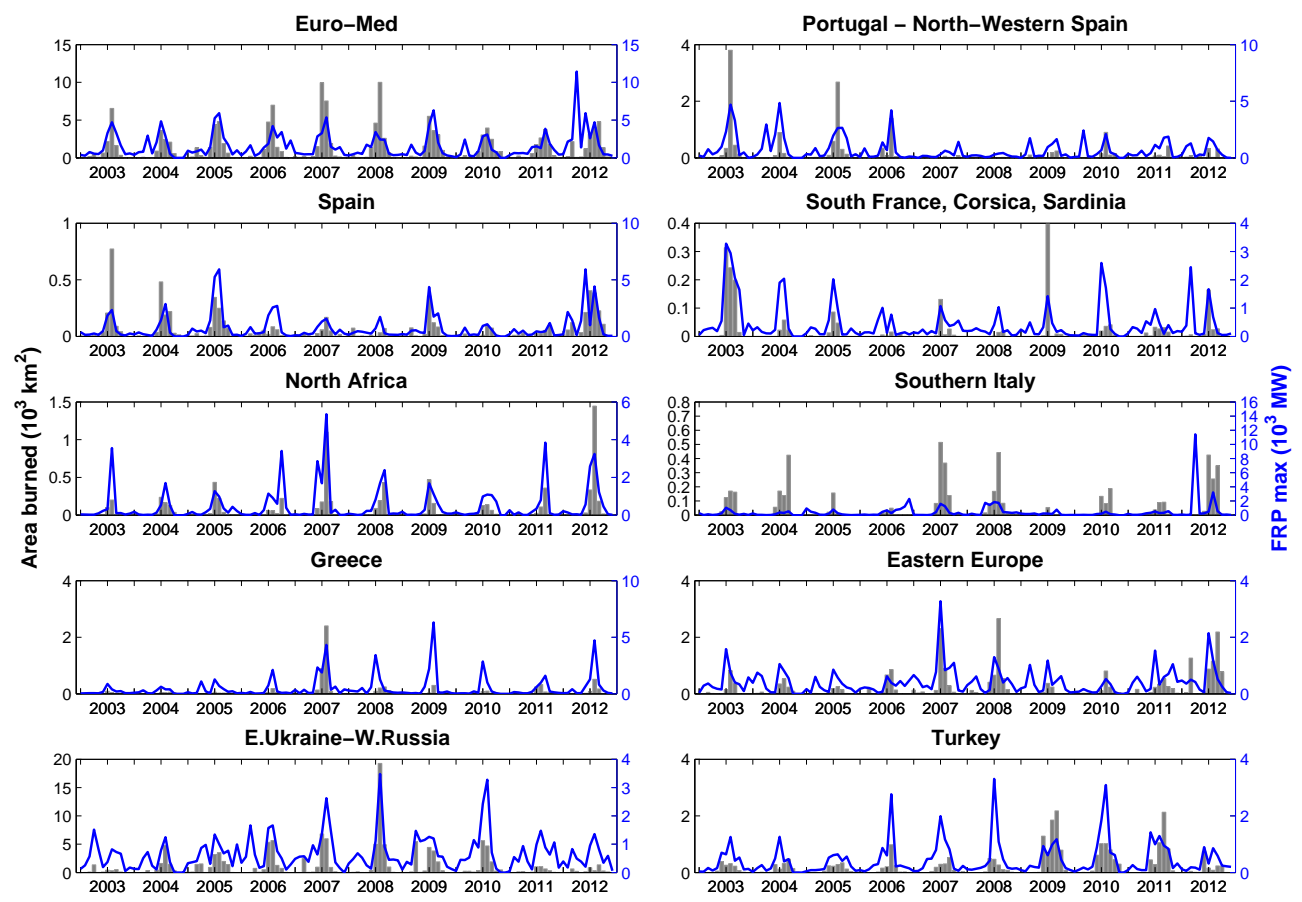

Fig. 4. Monthly burned area (bar plot) according to the MODIS MCD64 product (500 m resolution) for the 2003-2012 time period and within the main burning subregions. The corresponding maximum FRP detected is also plotted (solid line). Ticks on the $x$ axis correspond to January and July.

underestimate burned areas compared to the reported totals, by $20-30 \%$ for most countries, except Greece. For countries in eastern Europe and Turkey, the correlation is low and the reported totals are much lower than the observed values. This difference may be explained by the fact that the EFFIS reports only include burned areas in natural vegetation, while most of the burning in these regions is associated with agricultural practice, as discussed in the following section. Further validation would be required to better assess the quality of the burned area data in Europe, especially in the eastern countries.

Total monthly burned areas for the 2003-2012 time period and the main burning regions are presented in Fig. 4. In all regions, the maximum fire activity is reached during the summer months, but the fire season usually extends from June to September in the southern countries; until October in the eastern countries and Portugal. Significant burning also occurs in spring (March-April) in the eastern part of the domain (mostly agricultural fires). Interannual variability is also lower in these regions, with fires detected almost every year during the past decade. Southern countries, where fires are less frequent, are characterized by strong interannual variability. Several intense fire years are clearly noticeable: 2007 in the central and eastern Mediterranean area, 2003 and 2005 in Portugal, and 2012 in Spain, Italy and eastern Europe. Fires in western Russia were particularly strong in 2008 and 2010 (a strong event in the Moscow area for the latter).
The observed maximum FRP follows a similar pattern, with maximum values in August. FRP remains large during winter, although the number of fires detected decreases significantly. These detections may correspond to isolated fires or false detections that are not correctly filtered out. Note that for the 2010 fires in Russia, FRP is particularly strong.

The fire duration has been estimated as the number of consecutive days with a fire detected within a given $0.1^{\circ} \times 0.1^{\circ}$ grid cell. The average fire duration is mapped in Fig. 3 for the 2003-2012 time period. In order to avoid false variability due to missed detection (the presence of a cloud for instance), a 1 day gap is allowed. Although this does not provide a precise quantification of individual fire duration (several fires can occur within the considered grid cell, and large fires may spread through grid cells), this simple method gives a general overview of the durations of the events in the different regions. Figure 3 shows the spatial distribution on average for the years 2003-2012. The smaller fires in the eastern regions last generally for about 2 days, while large fires in the southern countries and western Russia can be detected during 4-10 days. These large fires, burning for long time periods, correspond to clusters of small fires resulting in mega fire events, as analyzed by San-Miguel-Ayanz et al. (2013).

\subsection{Vegetation type burned}

Figure 5 shows the relative contribution of each vegetation type in terms of area burned detection, using the CLC 

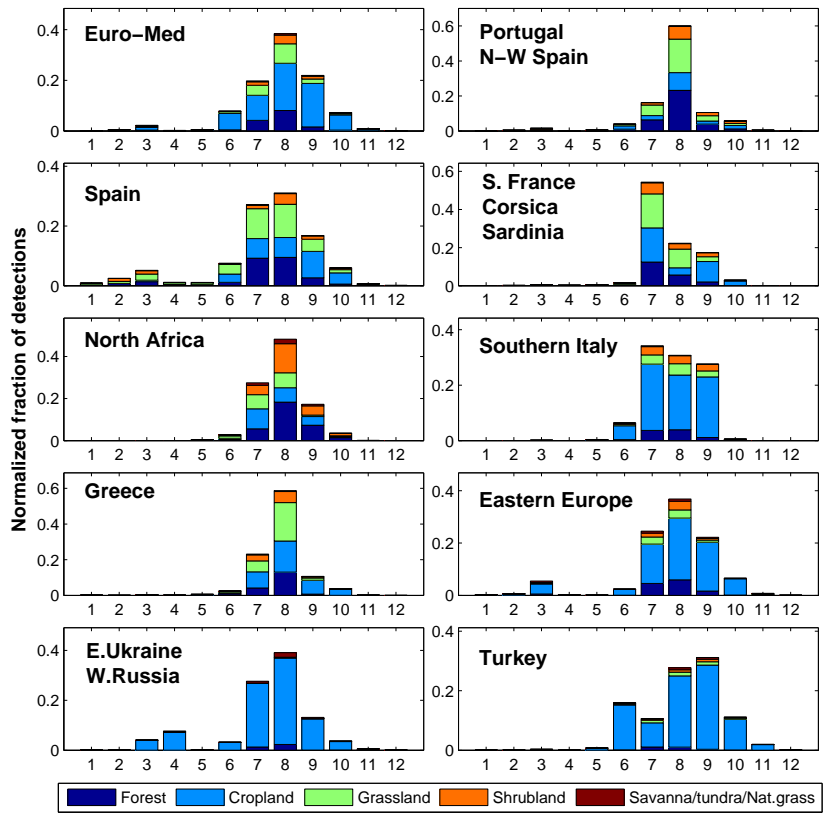

Fig. 5. Fraction of area burned detections located in different vegetation types for the CLC (grouped vegetation classes at $1 \mathrm{~km}$ resolution). For North Africa, Ukraine and Russia, the MODIS land cover is used.

database when available and MODIS MCD12 elsewhere (in this case North Africa, Ukraine and Russia).

During the summer months (July-August), about $48.5 \%$ of the fires are detected in croplands, $21.1 \%$ in forests, $20 \%$ in grasslands, $9 \%$ in shrubland and $1.4 \%$ in natural grassland. Fires in cropland are dominant in the eastern part of the domain, more specifically eastern Europe, Ukraine, western Russia, and Turkey, but also in southern Italy. Apart from Italy, forest and grassland fires are dominant in the Mediterranean countries. Forest fires contribute $39 \%$ of the fires in Portugal, $30 \%$ in Spain, $25 \%$ in southern France, Corsica and Sardinia, and $22 \%$ in Greece. Mediterranean shrubland only contributes a small fraction according to the CLC database, $10-13 \%$ on average in the Mediterranean area, while grassland contributes about $35-50 \%$.

Fires in spring mainly occur in croplands in eastern Europe and Ukraine. The fraction of croplands also tends to increase later in the season (September-November).

These general features remain consistent if MODIS or USGS land covers are used. The main difference is that MODIS or USGS attribute larger fractions of area burned in shrubland in the Mediterranean countries, that corresponds to grassland in the CLC classes. USGS also tends to attribute more fires in croplands.

Peatland burning is not mentioned in Fig. 5 because its contribution on average over the domain is negligible. For the 2010 fires in Russia, the large event in the Moscow area was partly located in peatlands, which contributed to $30 \%$ of the $\mathrm{CO}$ emissions according to Konovalov et al. (2011). For this event, no fires are detected in the MCD12 wetland category. This highlights the need for a more precise database specific to peatlands in this region.

As already mentioned, the difficulty in attributing the burned vegetation on a regional scale precisely is one of the main uncertainties in the methodology. The uncertainty associated with the choice of land use will be discussed further in Sect. 7.

\subsection{Diurnal variability of fire radiative power}

Geostationary observations of the fire radiative power from SEVIRI are used to estimate the diurnal cycle. The hourly variability of the number of detected fires, and the corresponding average variability of FRP within the main burning regions are shown in Fig. 6.

For all regions, the diurnal cycle of the number of fires detected is very pronounced, with a peak in the afternoon, between 14:00 and 16:00 local time (LT). In Italy and in the eastern part of the domain, the number of fires is high throughout the day, with a secondary maximum in the morning (08:00-10:00 LT). The large fraction of fires attributed to cropland in these regions may explain the differences. The number of fires detected at night remains significant, except for eastern Europe.

In terms of FRP, the diurnal cycles are less contrasted and the peak values are on average observed earlier in the afternoon (01:00-04:00 pm). The profiles are more consistent between regions, except for southern Italy.

Mu et al. (2011) analyzed diurnal variations of fires above North America using the GOES geostationary observations (WF-ABBA). They find a clear peak in the afternoon (12:0016:00 LT) for all regions and all types of vegetation, going down to almost zero at night in croplands in North America and for all vegetation in Central and South America. Our results suggest that these profiles can not be applied to Europe. Roberts et al. (2009) analyzed the diurnal cycle of fires in Africa using the SEVIRI observations and showed a peak at around 14:00 LT and low fire activity between midnight and 07:00 LT. Their results were consistent in terms of number of detections and FRP value, and for all vegetation types. They note however that some strong variability can be observed due to cloud cover contamination.

Detection is also more difficult for smaller, smoldering fires, that can still emit large amounts of trace gases and aerosols. A smaller amount of fires detected during the night can thus suggest that flaming fires are lower, but smoldering can remain. For wildfires remaining active several days, emissions should not become zero at night.

For this reason, and because FRP is directly linked to the fuel consumption, we have chosen to estimate the diurnal cycle based on the FRP rather than the number of fires. The FRP hourly variation's profiles are normalized and used in the emission model to estimate the diurnal cycle of the emissions. 

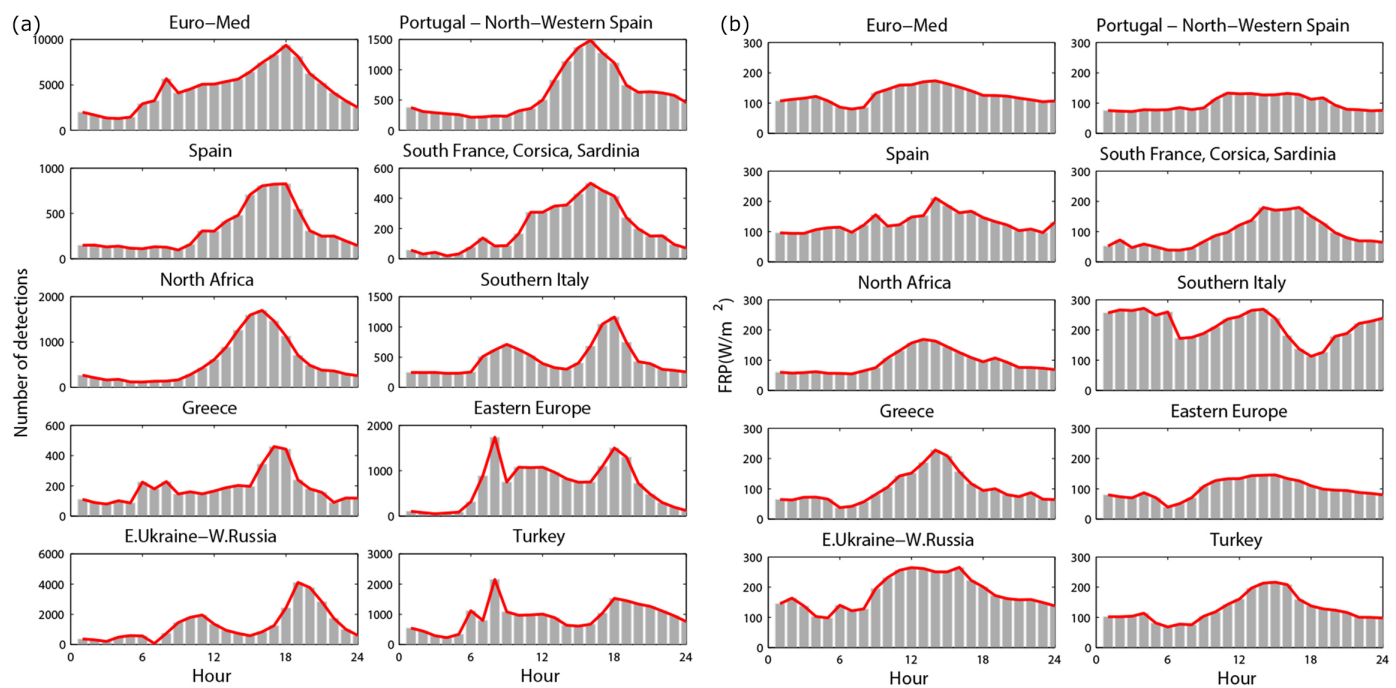

Fig. 6. Hourly variation of the number of fires detected by the MSG/SEVIRI instrument (a) and of the average FRP measurements over several subregions of the domain for the 2008-2010 time period (July-August only). The red line shows the corresponding averaged diurnal cycle.

\section{High-resolution emission model}

This section describes the first version (v1.0) of the APIFLAME emission model. The approach used follows the formulation of Seiler and Crutzen (1980). For each emitted species $i$ considered (trace gas or aerosol), the emission associated with a detected fire $E_{i}(\mathrm{~g})$ is estimated by multiplying the total area burned $A\left(\mathrm{~m}^{2}\right)$ by the fraction of each vegetation type $v, f_{v}$, the fuel load consumed, i.e., the quantity of biomass susceptible to burning or fuel consumption factor $F_{v}\left(\mathrm{~kg}\right.$ dry matter $(\mathrm{DM}) \mathrm{m}^{-2}$ ), which also depends on vegetation, and the specific emission factor for the considered species and vegetation type $\epsilon_{v, i}\left(\mathrm{~g}(\mathrm{kgDM})^{-1}\right)$, as summarized in the following equation:

$E_{i}=A \sum_{v=1}^{\text {veg_types }} f_{v} F_{v} \epsilon_{v, i}$.

Any chemical species may be included in the inventory if the corresponding emission factor for each vegetation class, $\epsilon_{v, i}$, is known. Eq. (1) is applied at fire resolution (depending on the resolution of the area burned or active fire database used): for each fire detection, each parameter of the calculation are estimated to calculate the corresponding emissions for a list of species. The emissions are then binned into a specified grid, with resolution ranging from a few kilometers to several hundreds kilometers, depending on applications. For a given fire location and associated area burned, the steps necessary for the computation of Eq. (1) are described in the following subsections. A general scheme of the emission model is provided in Fig. 7.

\subsection{Fuel load consumed}

The fuel load available for burning is calculated by multiplying the biomass density $\left(B_{p}\right.$ in $\left.\mathrm{kgCm}^{-2}\right)$ of each considered carbon pool $p$ in the region of the fire by the fraction of vegetation that is expected to actually burn (burning fraction $\beta$ ). The fuel consumed is then deduced by multiplying the available fuel load by the combustion fraction $(C)$, such that:

$F_{v}=\sum_{p=1}^{\text {carbon_pools }} C_{v} \beta_{p} B_{p, v}$.

The fuel load consumed is converted from $\mathrm{kgCm}^{-2}$ to $\mathrm{kg} \mathrm{DM} \mathrm{m}^{-2}$ assuming a $48 \%$ carbon content in DM (following van der Werf et al., 2010).

The biomass density is estimated using the ORCHIDEE model, as described in Sect. 2.2. Although global data sets of soil (Nachtergaele et al., 2012) and vegetation carbon content (Gibbs, 2006) exist at fine spatial resolution, here we used the ORCHIDEE model to estimate the biomass density because these data sets do not discriminate the fraction of each pool $(p)$ contributing to the total carbon content.

The combustion completeness (or burning efficiency) corresponds to the ratio of fuel load consumed to total available biomass. It is difficult to estimate since it is influenced by vegetation characteristics such as age, phenology, and moisture content, but it also depends on fire behavior, such as fire line intensity, fire rate of spread, and flame residence time. The burning efficiencies are often estimated from fuel consumption measurements in prescribed or experimental fires (Rosa et al., 2011). In general, fine and dry fuels burn more completely than coarse and wet fuels (van der Werf et al., 2006). 


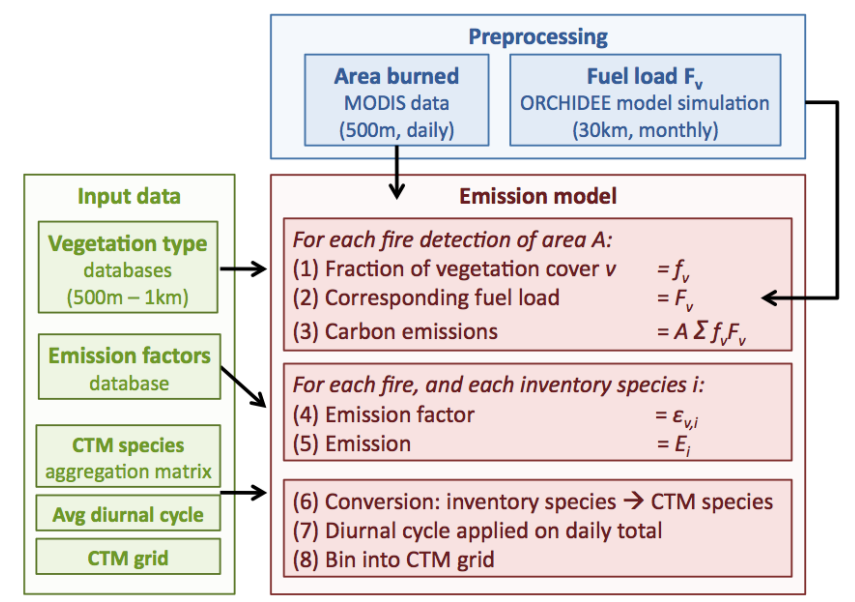

Fig. 7. Schematic representation of the APIFLAME emissions' model.

The fraction of biomass available for burning is first estimated using values of $\beta_{p}$ recommended by Hoelzemann et al. (2004), and indicated in Table 3 for the ORCHIDEE PFTs. Minimum and maximum values show a large range of variations. A simplified parameterization (linear interpolation) based on moisture stress is used to determine whether combustion is closer to the lower or upper limit: the minimum scenario is used for wet regions/seasons, while the maximum scenario is used for the dry ones. Vegetation moisture stress from the ORCHIDEE simulations is used. It is calculated from relative soil moisture by convolution of this relative soil moisture to an exponential root density decrease. The exponent coefficient depends on the PFT. For instance grass and crops are mainly sensitive to the first $50 \mathrm{~cm}$ of the soil whereas trees are sensitive to up to $2 \mathrm{~m}$. The global simulation generally shows slightly drier conditions than the regional one, more specifically in summer. Hence, while carbon load is lower, the fraction available for burning will be higher.

The averaged regional values of available fuel loads for the Euro-Mediterranean region and each scenario for the example of the summer 2007 are shown in Table 4. For each type of vegetation, only grid cells where contributing PFTs correspond to more than $75 \%$ of the vegetation cover are considered. The variability among scenarios is largest for the forest PFTs. Using the global ORCHIDEE simulation results in available fuel loads lower by almost $50 \%$ for forest $\left(3.66 \mathrm{~kg} \mathrm{~m}^{-2}\right)$, by about $10 \%$ for agriculture $\left(2.67 \mathrm{~kg} \mathrm{~m}^{-2}\right)$ and larger by about $26 \%$ for grassland $\left(1.48 \mathrm{~kg} \mathrm{~m}^{-2}\right)$. Note that fuel loads are scaled by the fraction of grid cell occupied by the specific PFT (total carbon being a weighted average of the carbon density within each PFT). Due to inhomogeneosities within the grid cells, this naturally results in lower values than if only one PFT is assumed. The lower horizontal resolution of the global simulation may thus explain part of the differences in the average available fuel loads provided here.

Hoelzemann et al. (2004) report values of available biomasses of 0.8 and $1.4 \mathrm{~kg} \mathrm{~m}^{-2}$ for savanna in western and eastern Europe, respectively, and of 7.5 and $11.8 \mathrm{~kg} \mathrm{~m}^{-2}$ for forests. The values used here are thus on the lower end for forests, but in good agreement for grasslands. The uncertainty related to this parameter is explored through the calculation of the emissions for the four scenarios: tabulated minimum, average or maximum values as well as the variation according to moisture stress (cf. Sect. 7).

Once the available fuel load is estimated, a combustion fraction $\left(C_{v}\right)$ is applied, again following Hoelzemann et al. (2004): $C_{v}$ is set equal to 0.6 for forest PFTs, 0.85 for grassland and agriculture. For summertime intense fires in the Mediterranean area, a value of 0.85 is used for $C_{v}$ for all PFTs.

In the case of fires detected in peatlands, since the ORCHIDEE simulations used here do not have information on the ground layer organic matter, and since peatlands do not correspond to a specific PFT (cf. Sect. 2.2), the amount of fuel consumed is based on values from the literature. In tropical regions, a fuel consumption equal to $48.75 \mathrm{~kg} \mathrm{DMm}^{-2}$ is used, following values reported by Levine (1999) for Indonesian fires. In boreal regions of North America and Eurasia, a fuel consumption of $6.8 \mathrm{kgDMm}^{-2}$ is used for early season burning (before $15 \mathrm{July}$ ) and of $7.5 \mathrm{kgDMm}^{-2}$ for late season burning (drier fuels after 15 August) using results from Turetsky et al. (2011a). Between mid-July and mid-August, a linear increase is assumed, following the approach used in Turquety et al. (2007). In other mid-latitude regions, a fuel consumption of $20 \mathrm{~kg} \mathrm{DMm}^{-2}$, reported for fires in Scotland by Davies et al. (2013), is used. Note that uncertainties in these values are very large. For boreal fires for instance, Turetsky et al. (2011b) report fuel consumption values of $33.2 \mathrm{~kg} \mathrm{DM} \mathrm{m}^{-2}$ in drained peatlands.

\subsection{Emission factors}

The species and corresponding emission factors used are listed in Table 5. The values from the recent review of Akagi et al. (2011) are used for most species, complemented with the Andreae and Merlet (2001) database for missing values. Emission factors are provided in terms of $\mathrm{g}$ species per $\mathrm{kg}$ DM burned $\left(\mathrm{g} \mathrm{kg}^{-1}\right)$ for all relevant species observed in burning plumes (from field or laboratory measurements) and for different standard vegetation types (tropical forest, temperate and extratropical forest, boreal forest, crop residue, pasture maintenance, savanna). Once the fuel burned is estimated (DM burned), emissions for a large series of trace gases and aerosols can be calculated.

The type corresponding to a specific fire is attributed using the vegetation type provided by the landuse classification (CLC, MODIS or USGS). Correspondence between the 
Table 3. Fraction of vegetation available for burning in the considered carbon pools (following Hoelzemann et al., 2004). The minimum and maximum values are given in parentheses.

\begin{tabular}{lrrrr}
\hline ORCHIDEE PFT & Litter & Leaf & Wood & Roots \\
\hline Tropical broad-leaved evergreen & 100 & $10(5-20)$ & 0 & 0 \\
Tropical broad-leaved raingreen & 100 & $10(5-20)$ & 0 & 0 \\
Tropical needleleaf evergreen & 100 & $30(15-60)$ & $10(5-20)$ & 0 \\
Temperate broad-leaved evergreen & 100 & $30(15-60)$ & $10(5-20)$ & 0 \\
Temperate broad-leaved summergreen & 100 & $20(10-40)$ & $10(5-20)$ & 0 \\
Boreal needleleaf evergreen & 70 & $20(10-40)$ & $20(10-40)$ & $5(2.5-10)$ \\
Boreal broad-leaved summergreen & 70 & $20(10-40)$ & $20(10-40)$ & $5(2.5-10)$ \\
Boreal needleleaf summergreen & 70 & $20(10-40)$ & $20(10-40)$ & $5(2.5-10)$ \\
C3 grass & 100 & $50(25-100)$ & $5(2.5-10)$ & 0 \\
C4 grass & 100 & $50(25-100)$ & $5(2.5-10)$ & 0 \\
C3 agriculture & 100 & $50(25-100)$ & $5(2.5-10)$ & 0 \\
C4 agriculture & 100 & $50(25-100)$ & $5(2.5-10)$ & 0 \\
\hline
\end{tabular}

vegetation types is indicated in Table 1 for the CLC database (used by default over Europe). For example, if a fire is detected in a "mixed cropland and forest" vegetation, the emission factor is estimated to be the average of the emission factors for crop residue and forest. If emission factors for temperate or boreal forests are not provided, values of extratropical forests are used (reported as "temperate" in the table above). If no emission factor is available for chaparral, then we use values for shrubland, which correspond to the average of savanna and temperate forest.

The emission factors reported for chaparral in Akagi et al. (2011) are used for Mediterranean shrubland (sclerophyllous in the CLC classes, shrublands at latitudes between 30 and $35^{\circ} \mathrm{N}$ for other landuse databases). Values are significantly lower than for other vegetation types for compounds favored by the smoldering phase, like CO. Measurements in prescribed burning of shrubland vegetation in Portugal confirm this behavior, but report even lower values $\left(\sim 35 \mathrm{~g} \mathrm{~kg}^{-1}\right.$ for CO) (Alves et al., 2010). Alves et al. (2011) report emission factors for typical wildfires in Portugal, which occured during the summer of 2009 and mainly affected forests. These values are, on the contrary, significantly larger than those used in this study. For example, $\mathrm{CO}$ emission factors of $231 \pm 117 \mathrm{~g} \mathrm{~kg}^{-1}$ were measured, 2.6 times larger than those used here for extratropical forests. For OC, the values measured are on average $15.8 \mathrm{~g} \mathrm{~kg}^{-1}, 70 \%$ larger than those used here. In a recent analysis of forest wildfires over the northern United States, Urbanski (2013) also found higher emission factors than Akagi et al. (2011), of $135.4 \mathrm{~g} \mathrm{~kg}^{-1}$ for CO and $23.2 \mathrm{~g} \mathrm{~kg}^{-1}$ for $\mathrm{PM}_{2.5}$. This suggests that the values for extra-tropical fires in Akagi et al. (2011) are too low. There is a clear need for more observations in order to reduce the large uncertainties regarding emission factors.

Emissions of inventory species may then be converted to emissions of model species depending on the chemical mechanism used in the chemistry-transport model using an aggregation matrix. This matrix allows adaptability to new
Table 4. Average summertime available fuel load for the EuroMediterranean region in terms of carbon $\left(\mathrm{kg} \mathrm{m}^{-2}\right)$ according to the regional ORCHIDEE simulation.

\begin{tabular}{lrrr}
\hline Scenario & Forest & Grassland & Agriculture \\
\hline Min & 4.69 & 0.98 & 2.94 \\
Mean & 6.69 & 1.17 & 2.97 \\
Max & 9.21 & 1.2 & 3.04 \\
Var & 6.93 & 1.17 & 2.99 \\
\hline
\end{tabular}

chemical schemes. The emission factors list and the aggregation matrix need to be modified accordingly, but no modification of the core of the emission model is required.

\subsection{Diurnal cycle of fires' emission fluxes}

Once the daily emissions are calculated using the daily burned area, the emissions may be redistributed throughout the day using a prescribed diurnal cycle.

Studies over North America have used the variability in the number of active fires detected during the day by the geostationary GOES instrument (Mu et al., 2011). For Europe, it can be estimated based on the observations by the MSG/SEVIRI instrument. As discussed in Sect. 4.3, the associated diurnal variations are very dependent on the region and the fire event considered. Although fire activity seems to decrease during the night, it is not true for all regions. The analysis of the impact of the higher temporal variability in emissions on fire plumes' transport conducted by $\mathrm{Mu}$ et al. (2011) has shown that the daily variability is more critical than the hourly variability.

For these reasons, the current version of the algorithm does not provide precise processing of diurnal variability, but allows the use of an average diurnal profile, adjusted for the Euro-Mediterranean region using the MSG/SEVIRI observations (cf. Sect. 4.3). 
Table 5. Emission factors (in $\mathrm{g} \mathrm{kg}^{-1} \mathrm{DM}$ ) used for the species included in the inventory. All numbers are from the review by Akagi et al. (2011), except noted otherwise.

\begin{tabular}{|c|c|c|c|c|c|c|c|c|}
\hline Species & $\begin{array}{r}\text { Tropical } \\
\text { Forest }\end{array}$ & Savanna & $\begin{array}{r}\text { Crop } \\
\text { residue }\end{array}$ & $\begin{array}{r}\text { Pasture } \\
\text { Maintenance }\end{array}$ & $\begin{array}{r}\text { Boreal } \\
\text { forest }\end{array}$ & $\begin{array}{r}\text { Temperate } \\
\text { forest }\end{array}$ & Peatland & Chaparral \\
\hline $\mathrm{CO}_{2}$ & 1643 & 1686 & 1585 & 1548 & 1489 & 1637 & 1563 & 1710 \\
\hline $\mathrm{CO}$ & 93 & 63 & 102 & 135 & 127 & 89 & 182 & 67 \\
\hline $\mathrm{CH}_{4}$ & 5.07 & 1.94 & 5.82 & 8.71 & 5.96 & 3.92 & 11.8 & 2.51 \\
\hline $\mathrm{C}_{2} \mathrm{H}_{2}$ & 0.44 & 0.24 & 0.27 & 0.21 & 0.18 & 0.29 & 0.14 & 0.20 \\
\hline $\mathrm{C}_{2} \mathrm{H}_{4}$ & 1.06 & 0.82 & 1.46 & 1.28 & 1.42 & 1.12 & 1.79 & 0.75 \\
\hline $\mathrm{C}_{2} \mathrm{H}_{6}$ & 0.71 & 0.66 & 0.91 & 0.95 & 1.79 & 1.12 & - & 0.36 \\
\hline $\mathrm{C}_{3} \mathrm{H}_{4}$ & 0.02 & 0.01 & - & 0.02 & - & - & - & - \\
\hline $\mathrm{C}_{3} \mathrm{H}_{6}$ & 0.64 & 0.79 & 0.68 & 0.85 & 1.13 & 0.95 & 2.30 & 0.38 \\
\hline $\mathrm{C}_{3} \mathrm{H}_{4}$ & - & - & - & - & $0.06^{\mathrm{g}}$ & - & - & - \\
\hline $\mathrm{C}_{3} \mathrm{H}_{8}$ & 0.13 & 0.10 & 0.28 & 0.22 & 0.44 & 0.26 & - & 0.19 \\
\hline Isoprene & 0.13 & 0.04 & 0.38 & 0.12 & $0.15^{\mathrm{g}}$ & - & 1.07 & - \\
\hline $\mathrm{C}_{6} \mathrm{H}_{6}$ & 0.39 & 0.20 & 0.15 & 0.70 & $1.11^{\mathrm{g}}$ & - & 2.46 & - \\
\hline Toluene & 0.26 & 0.08 & 0.19 & 0.34 & $0.48^{\mathrm{g}}$ & - & 1.21 & - \\
\hline Xylene & 0.11 & 0.01 & - & 0.11 & $0.18^{\mathrm{g}}$ & - & - & - \\
\hline Terpenes & - & - & - & - & $3.09^{\mathrm{g}}$ & - & - & - \\
\hline $\mathrm{C}_{2} \mathrm{H}_{5} \mathrm{OH}$ & - & - & - & - & $0.05^{\mathrm{g}}$ & - & - & - \\
\hline $\mathrm{CH}_{3} \mathrm{OH}$ & 2.43 & 1.18 & 3.29 & 5.84 & 2.82 & 1.93 & 5.36 & 0.80 \\
\hline Phenol & 0.45 & 0.52 & 0.52 & 1.68 & 2.96 & 0.33 & 4.36 & 0.45 \\
\hline $\mathrm{HCHO}$ & 1.73 & 0.73 & 2.08 & 1.90 & 1.86 & 2.27 & 1.69 & 0.83 \\
\hline $\mathrm{CH}_{3} \mathrm{COCH}_{3}$ & 0.63 & 0.16 & 0.45 & 1.05 & $0.75^{\mathrm{g}}$ & - & 1.08 & - \\
\hline MVE & - & 0.16 & 0.08 & - & - & - & 0.85 & - \\
\hline Acetic acid & 4.08 & 3.82 & 6.89 & 10.66 & 5.15 & 2.43 & 7.78 & 1.178 \\
\hline OCS & 0.02 & - & - & - & $0.46^{\mathrm{g}}$ & - & 1.20 & - \\
\hline $\mathrm{NH}_{3}$ & 1.33 & 0.52 & 2.17 & 1.47 & 2.72 & 0.78 & 10.8 & 1.03 \\
\hline $123 \mathrm{TMB}$ & - & - & - & - & $0.05^{\mathrm{g}}$ & - & - & - \\
\hline $124 \mathrm{TMB}$ & - & - & - & - & $0.03^{\mathrm{g}}$ & - & - & - \\
\hline $135 \mathrm{TMB}$ & - & - & - & - & $5.86 \times 10^{-3 \mathrm{~g}}$ & - & - & - \\
\hline $\mathrm{AROM}^{\mathrm{a}}$ & 0.06 & 0.01 & - & - & $0.13^{\mathrm{g}}$ & - & - & - \\
\hline $\mathrm{ALKA}^{\mathrm{b}}$ & 0.07 & 0.04 & 0.15 & 0.06 & 0.35 & 0.08 & - & 0.14 \\
\hline $\mathrm{ALKEN}^{\mathrm{c}}$ & 0.30 & 0.16 & 0.50 & 0.37 & 0.48 & - & - & - \\
\hline ALDEHS $^{\mathrm{d}}$ & 2.26 & 1.16 & 2.71 & 2.78 & 0.62 & 0.18 & 4.73 & 0.17 \\
\hline KETON $^{\mathrm{e}}$ & 1.06 & - & - & 3.5 & $0.43^{\mathrm{g}}$ & - & - & - \\
\hline FURANS $^{\mathrm{f}}$ & 2.29 & 0.17 & 0.11 & 2.63 & 0.8 & 0.2 & 1.51 & 0.18 \\
\hline $\mathrm{SO}_{2}$ & 0.40 & 0.48 & $0.4^{\mathrm{h}}$ & 0.32 & $1 . \mathrm{g}, \mathrm{h}$ & $1 . \mathrm{g}, \mathrm{h}$ & - & 0.68 \\
\hline HONO & 1.18 & 0.20 & 0. & 0.16 & 0. & 0.52 & 0. & 0.41 \\
\hline $\mathrm{NO}_{X}$ & 2.55 & 3.9 & 3.11 & 0.75 & 0.90 & 2.51 & 0.8 & 3.26 \\
\hline $\mathrm{N}_{2} \mathrm{O}$ & - & - & - & - & 0.41 & 0.16 & - & 0.25 \\
\hline $\mathrm{BC}$ & 0.52 & 0.37 & 0.75 & 0.91 & - & $0.56^{\mathrm{g}}$ & 0.20 & 1.3 \\
\hline OC & 4.71 & 2.62 & 2.30 & 9.64 & - & $9.2^{\mathrm{g}}$ & 6.23 & 3.7 \\
\hline $\mathrm{PM}_{2.5}$ & 9.1 & 7.17 & 6.26 & 14.8 & 15.3 & 12.7 & - & 11.9 \\
\hline Total PM & 18.5 & $8.5^{\mathrm{h}}$ & $6.26^{\mathrm{h}}$ & 28.9 & $17.6^{\mathrm{g}, \mathrm{h}}$ & $17.6^{\mathrm{g}, \mathrm{h}}$ & - & - \\
\hline
\end{tabular}

a AROM: the aromatics other than benzene, toluene, and trimethylbenzene (Molar mass $M=126 \mathrm{~g} \mathrm{~mol}^{-1}$ ); ${ }^{\mathrm{b}}$ ALKAN: butanes and heavier alcanes $\left(M=58 \mathrm{~g} \mathrm{~mol}^{-1}\right){ }^{\mathrm{c}}$ ALKEN: butenes and heavier alcenes $\left(M=56 \mathrm{~g} \mathrm{~mol}^{-1}\right){ }^{\mathrm{d}} \mathrm{ALDEHS}$ aldehydes other than formaldehyde $(M=44 \mathrm{~g} \mathrm{~mol}-1)$; e KETONS: cetones other than acetone $\left(M=72 \mathrm{~g} \mathrm{~mol}^{-1}\right) ;{ }^{\mathrm{f}}$ FURANS: furans $\left(M=82 \mathrm{~g} \mathrm{~mol}^{-1}\right) ;{ }^{\mathrm{g}}$ Values for extratropical forest, also used for temperate forests; ${ }^{\mathrm{h}}$ Values from Andreae and Merlet (2001).

\subsection{Comparing methodology to other inventories}

The results obtained are compared to several widely used inventories: GFEDv3 (van der Werf et al., 2010), FINNv1 (Wiedinmyer et al., 2011) and GFASv1 (Kaiser et al., 2012). These inventories are all global, daily to 3-hourly, and based on the MODIS observations of fire activity. Their main characteristics are summarized in Table 6 .

GFEDv3 uses area burned data, combined to active fires for the high temporal variability (Mu et al., 2011). FINN and GFAS were designed to provided emissions on a near-real 
Table 6. Approaches and parameters used in the inventories compared. AB stands for area burned, NB for the number of active fires, and FRP for the fire radiative power.

\begin{tabular}{lcccc}
\hline & APIFLAMEv1 & GFEDv3 & FINNv1 & GFASv1 \\
\hline Method & $\begin{array}{c}\text { Eq. (1) } \\
\text { Daily } \\
500 \mathrm{~m}\end{array}$ & $\begin{array}{c}\text { Eq. (1) } \\
\text { Daily, 3 } \mathrm{h} \\
0.5^{\circ} \times 0.5^{\circ}\end{array}$ & $\begin{array}{c}\text { Eq. (1) } \\
\text { Daily } \\
1 \mathrm{~km}\end{array}$ & $\begin{array}{c}\text { Top-down } \\
\text { Daily } \\
0.5^{\circ} \times 0.5^{\circ}\end{array}$ \\
\hline $\begin{array}{l}\text { Fire } \\
\text { data }\end{array}$ & AB & AB, NB & NB & FRP \\
& MCD64 & MCD64, & MOD14 & MOD14 \\
\hline$F_{v}$ & ORCHIDEE & CASA-GFED & Tabulated & $\begin{array}{c}\text { Function } \\
\text { of FRP }\end{array}$ \\
& model & model & & $\begin{array}{c}\text { Andreae } \\
\text { and Merlet } \\
\text { (main }\end{array}$ \\
source) & Akagi & Andreae & Akagi & et al. \\
and Merlet & $(2011)$ & $(2001)$ & $(2011)$ & $(2001)$ \\
\hline
\end{tabular}

time basis. They are therefore using the active fire detection from MODIS.

GFED and FINN both use a bottom-up approach, calculating emissions using Eq. (1). For FINN, the fuel load consumed is based on the tabulated values provided by Hoelzemann et al. (2004) for Europe (not for all regions). For GFED, modeling of the carbon cycle (the CASA-GFED model) is used, which accounts for the impact of observed fires. In this study, offline simulations of the ORCHIDEE model are used, without interaction with the detected fires.

GFAS uses a top-down approach, estimating carbon emissions from the fire intensity (FRP measurements). The emission factors are from the (Andreae and Merlet, 2001) database for GFED and GFAS, and from the (Akagi et al., 2011) database for FINN. In the following, the area burned estimates are compared to the GFED and FINN area burned, and emissions for the main compounds are compared to GFED, FINN and GFAS.

\section{Regional fire emissions}

The variability of fire emissions is mainly due to the variability of fire activity itself, as discussed for Europe and the Mediterranean area in Sect. 4. In this section, the monthly $\mathrm{CO}$ emissions are presented and compared to the GFED and GFAS inventories. The contribution of fires to the regional pollution budget in terms of average over the past $10 \mathrm{yr}$ is then discussed. Results are presented for the default configuration of the emissions' model, which uses the MODIS MCD64 area burned, the CLC vegetation database, the regional ORCHIDEE simulation with burning fraction varying depending on moisture stress. Sensitivity to the chosen configuration is discussed in Sect. 7.2.

\subsection{Comparison of monthly emissions of $\mathrm{CO}$}

The monthly areas burned described in Sect. 4 have first been compared to the GFEDv3 area burned for the 2003-2010 time period. Since the same initial area burned products from MODIS have been used (Giglio et al., 2010), these comparisons show very good correlations $(>0.98)$ and relative differences of $14 \%$ on average (lower in GFEDv3).

In southern Italy and Turkey, the correlation reaches 0.89 but the GFED monthly area burned is on average $52 \%$ and $40 \%$ higher, respectively. The low bias in southern Italy is mainly due to a temporal shift, while the area burned in Turkey is lower during the full fire seasons, especially before 2008. These differences may be attributed to differences in the processing of the MCD64 area burned product, more specifically the fraction of vegetated cover used to scale the $500 \mathrm{~m} \times 500 \mathrm{~m}$ pixels. The combined use of area burned and active fires in GFEDv3 also affects temporal variability.

The resulting monthly $\mathrm{CO}$ emissions are shown in Fig. 8 for the calculation based on the CLC and the MODIS MCD12 vegetation types, as well as for the GFEDv3 and GFASv1 inventories. The temporal variations are consistent, in particular between this work and GFEDv3 due to the good correlations in area burned products. Correlations with GFASv1 is generally slightly lower $(0.86)$ due to the different variability of area burned and FRP, discussed in the Sect. 4. The different approaches used in the calculation of emissions result in larger discrepancies in the emitted mass.

In the Euro-Mediterranean region, the monthly emissions calculated in this work based on the CLC database are on average 2.5 times larger than GFEDv3, and $60 \%$ larger than GFASv1. When MODIS MCD12 vegetation is used, the emissions are 3 times larger than GFEDv3 and $100 \%$ larger than GFASv1. If only summer-time emissions are compared (largest values), the emissions based on either one of the vegetation maps (CLC or MOD12) are 2.5 larger than both GFEDv3 and GFASv1. During spring, when the fraction of cropland fires is higher, APIFLAME-CLC is 3.2 times larger than GFEDv3 and $39 \%$ lower than GFASv1, APIFLAMEMOD12 is 3.3 times larger than GFEDv3 and $27 \%$ lower than GFASv1, while GFASv1 is almost 28 times larger than GFEDv3 on average over the region. This indicates that during periods of low fire activity, the GFASv1 emission values are significantly higher than the other estimates. Again, this is due to relatively large FRP values observed throughout the year in the Euro-Mediterranean region (Fig. 4). Summer emissions are also significantly larger in GFASv1 above North Africa (70\% larger than our estimate, which is itself 4.4 times larger than GFEDv1), where very intense burning occurs in terms of FRP.

The largest differences are obtained in the eastern regions (eastern Europe, Ukraine, western Russia and Turkey) where the APIFLAME emissions are significantly higher, especially when the MODIS vegetation classification is used. This is not due to the area burned, since good agreement 


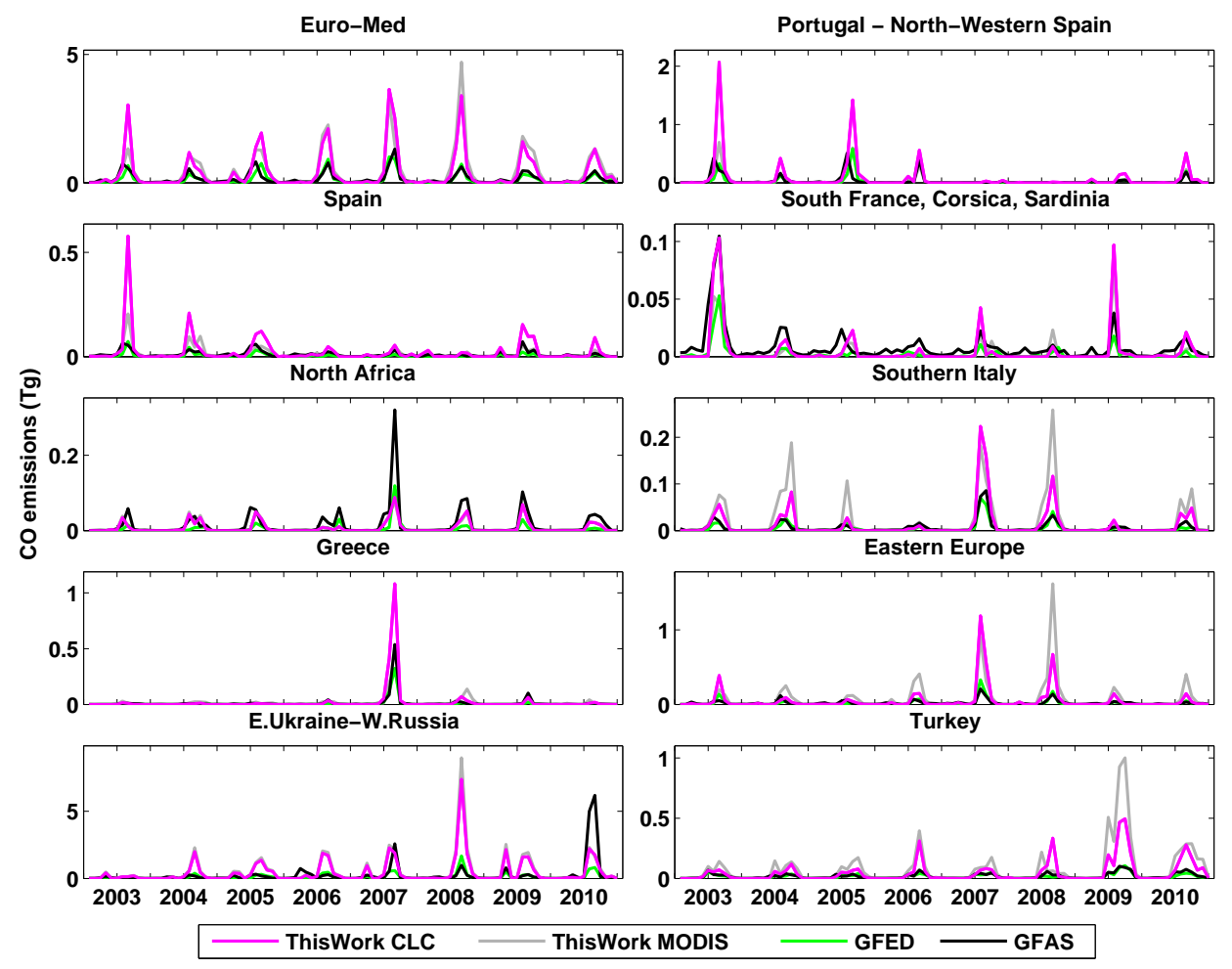

Fig. 8. Monthly emissions of CO in several subregions of Europe and the Mediterranean area according to this work, using CLC or MODIS MCD12 vegetation databases, and according to the GFEDv3 and the GFASv1 inventories. Detail on each inventory's specifications is provided in Table 6.

is found in all regions with GFEDv3, and even lower than GFEDv3 in Turkey. This may be explained by discrepancies in the fuel load estimates in these regions. Regions with the largest differences also often correspond to regions with the largest differences in vegetation attribution, especially in the fraction of forest, woodland and shrubland with respect to cropland, grassland and savanna. For example, during the summer of 2008, fires in eastern Europe attributed to cropland account for $93 \%$ of the carbon emissions in the APIFLAME inventory using the CLC vegetation map, for $99 \%$ if MOD12 vegetation is used, and only $75 \%$ in the GFEDv3 inventory (for which vegetation partitioning is provided). The larger contribution from croplands also explains the large differences in southern Italy in 2008 and Turkey in 2009. The fuel consumed per unit area burned in croplands is likely higher in the APIFLAME inventory than in GFEDv3. CO emission factors are also larger for crop burning, increasing the discrepancies. A more detailed comparison of the daily emissions, including a discussion of carbon emissions, is presented in Sect. 7 for the case of the summer of 2007, marked by particularly large fires.

A noticeable exception is the case of the Russian fires during the summer of 2010, for which GFASv1 emissions are significantly higher. During the large fires in northwestern Russia (latitude between 52 and $58^{\circ} \mathrm{N}$ and longitude between 35 and $\left.55^{\circ} \mathrm{N}\right), 11.3 \mathrm{Tg} \mathrm{CO}$ were emitted according to GFASv1, only $2.7 \mathrm{Tg}$ according to APIFLAME, and $1.9 \mathrm{Tg}$ according to GFEDv3. Kaiser et al. (2012) provide a full analysis of this case study. Large FRP values were measured, leading to large emissions. Moreover, fires were detected in peatlands that are included in GFESv1 through a specific land cover type and a specific conversion factor between FRP and fuel consumed (much higher than for other vegetation types). Peat burning is taken into account in GFEDv3 but mainly for Indonesia, and no contribution from peat is obtained for this event. As already mentioned, the APIFLAME inventory uses the MCD12 vegetation map in Russia, with peatland assumed in wetlands but no fire falls in this category during the summer of 2010. CO emission factors are also different. In GFASv1, peat burning emits $210 \mathrm{~g} \mathrm{~kg}^{-1}$ while in APIFLAME, we use a value of $182 \mathrm{~g} \mathrm{~kg}^{-1}$ from Akagi et al. (2011). A test has been performed using a mires mask to locate peat burning in Eurasia. $4 \%$ of the fires are then attributed to peatlands, resulting in emissions between 3 and $10 \mathrm{Tg} \mathrm{CO}$ (in good agreement with values calculated by Konovalov et al. (2011)) depending on the fuel consumption (average or drained peatlands) and the emission factor used. Additional work is clearly needed in boreal regions to better account for the specificities of ground layer burning, including peat burning. 


\subsection{Contributions to the regional emissions for the main pollutants}

Partitioning of area burned and $\mathrm{CO}$ and $\mathrm{NO}_{\mathrm{X}}$ emissions in the different vegetation classes, on average over the 20032012 time period, is shown in Table 7. Values are given for the inventory based on the CLC vegetation types, but similar results are obtained using MODIS MCD12.

The general conclusions from the analysis undertaken in Sect. 4.2 based on areas burned are still relevant in terms of emissions. The main contributing fires are located in croplands, then shrubland, forests and savanna (natural grassland). However, the contribution from different vegetation types for a given species also strongly depends on the emission factor. For $\mathrm{NO}_{\mathrm{X}}$, for example, fires in shrubland are contributing almost as much as fires in croplands. The contribution from peat burning is negligible in the EuroMediterranean region discussed here. This might be due to the MCD12 vegetation map (wetlands used as proxy for peatlands) used outside of the region covered by the CLC vegetation map.

Table 8 summarizes the mean annual emissions for some of the main pollutants emitted during the fires (merging all VOCs) for the Euro-Mediterranean region (latitudes between 36 and $48^{\circ} \mathrm{N}$ ), divided into three subdomains: West from $10^{\circ} \mathrm{W}$ to $5^{\circ} \mathrm{E}$, Central from 5 to $20^{\circ} \mathrm{E}$, and East from 20 to $35^{\circ} \mathrm{E}$. Again, it highlights the large discrepancies between inventories in terms of total emissions. For CO, our estimates are 3.7 times larger than the GFED inventory on average over the 2003-2010 time period. For NMVOCs and TPM (total particular matter), the results depend on the number of species included, so the results may not be consistent.

Table 9 provides a summary of the total annual regional emissions by country from both fires and anthropogenic activities (average for 2003-2011). This table only reports values for the countries most affected by fires and for which anthropogenic emissions from the EMEP inventory (Vestreng et al., 2007) are available. For these 14 countries, total fire emissions represent $28 \%$ of the total anthropogenic emissions for $\mathrm{PM}_{2.5}$ (diameter $<2.5 \mu \mathrm{m}$ ), $21 \%$ for $\mathrm{CO}, 14 \%$ for NMVOCs, $7 \%$ for coarse PM (diameter $>2.5 \mu \mathrm{m}$ ), $3 \%$ for $\mathrm{NH}_{3}, 2 \%$ for $\mathrm{NO}_{\mathrm{X}}$ and $0.3 \%$ for $\mathrm{SO}_{2}$. Hence, fires represent a significant pollution source for most regulated pollutants, all the more critical as it is concentrated in short time period. Indeed, fire events generally last less than $\sim 10$ days during fire seasons of only a few months (June-September), while anthropogenic emissions are almost constant throughout the year. On average over the past $10 \mathrm{yr}$, the most affected countries are Portugal, the countries of the Balkan Peninsula (Albania, Bosnia-Herzegovina, the republic of Macedonia, Greece), Moldova, Ukraine and Spain, which all have fire emissions representing more than $\sim 30 \%$ of the anthropogenic emissions for $\mathrm{CO}$ and $\mathrm{PM}_{2.5}$ (up to 136 and $156 \%$ for Portugal).
Table 7. Partitioning of area burned $(\mathrm{AB})$ and $\mathrm{CO}$ and $\mathrm{NO}_{\mathrm{X}}$ emissions for each CLC category, on average over the 2003-2010 time period, and in the Euro-Mediterranean area. The sum over large vegetation types is provided in the last lines of the table. About $1 \%$ of emissions are in other classes.

\begin{tabular}{lrrr}
\hline Class & $\mathrm{AB}(\%)$ & $\mathrm{CO}(\%)$ & $\mathrm{NO}_{\mathrm{X}}(\%)$ \\
\hline 1 & 33.6 & 16.1 & 14.6 \\
2 & 19.3 & 23.3 & 20.0 \\
3 & 0.9 & 0.7 & 0.8 \\
4 & 3.7 & 5.7 & 6.2 \\
5 & 0.7 & 1 & 0.9 \\
6 & 4.7 & 9.0 & 7.5 \\
7 & 3.0 & 4.8 & 3.9 \\
8 & 2.6 & 4.1 & 3.4 \\
9 & 9.5 & 6.4 & 9.0 \\
10 & 1.5 & 3.0 & 3.4 \\
11 & 5.2 & 5.4 & 6.5 \\
12 & 13.2 & 19.6 & 22.8 \\
\hline Cropland & 55 & 43 & 38 \\
Pasture & 1 & 1 & 1 \\
Forest & 11 & 18 & 15 \\
Savanna & 12 & 9 & 12 \\
Shrubland & 20 & 28 & 33 \\
\hline
\end{tabular}

\section{Uncertainty assessment in the case study of the summer of 2007}

The analysis of the uncertainty in the daily emissions is undertaken for the summer of 2007, which was affected by particularly strong fires in central and eastern Europe. Fires were most severe in Greece, with a total of $3138 \mathrm{~km}^{2}$ burned according to the EFFIS Forest Fires in Europe 2007 report (2008), and extreme pollution was transported across the Mediterranean basin (Turquety et al., 2009). The APIFLAME area burned for Greece during the summer of 2007 was $3290 \mathrm{~km}^{2}$, in good agreement (only $5 \%$ higher) with the value reported by EFFIS. There were also large fires in North Africa, southern Italy, the Balkans and eastern Europe. The analysis of the summer of 2007 case study will focus on these 6 subregions.

For the analysis of the general variability presented in Sect. 4, three additional subregions will be added to the west: Portugal, Spain, southern France, Corsica and Sardinia.

\subsection{Comparison of daily emissions to other inventories}

The daily burned area comparison to FINNv1 and GFEDv3 (cf. Sect. 5.4 for their respective characteristics) is shown in Fig. 9 for the main burning subregions.

All three estimates are in good general agreement, showing the main events at the same time with the same order of magnitude. The correlation between the different estimates is $\sim 0.9$. The total daily burned area over the EuroMediterranean region is on average $10 \%$ lower than the 

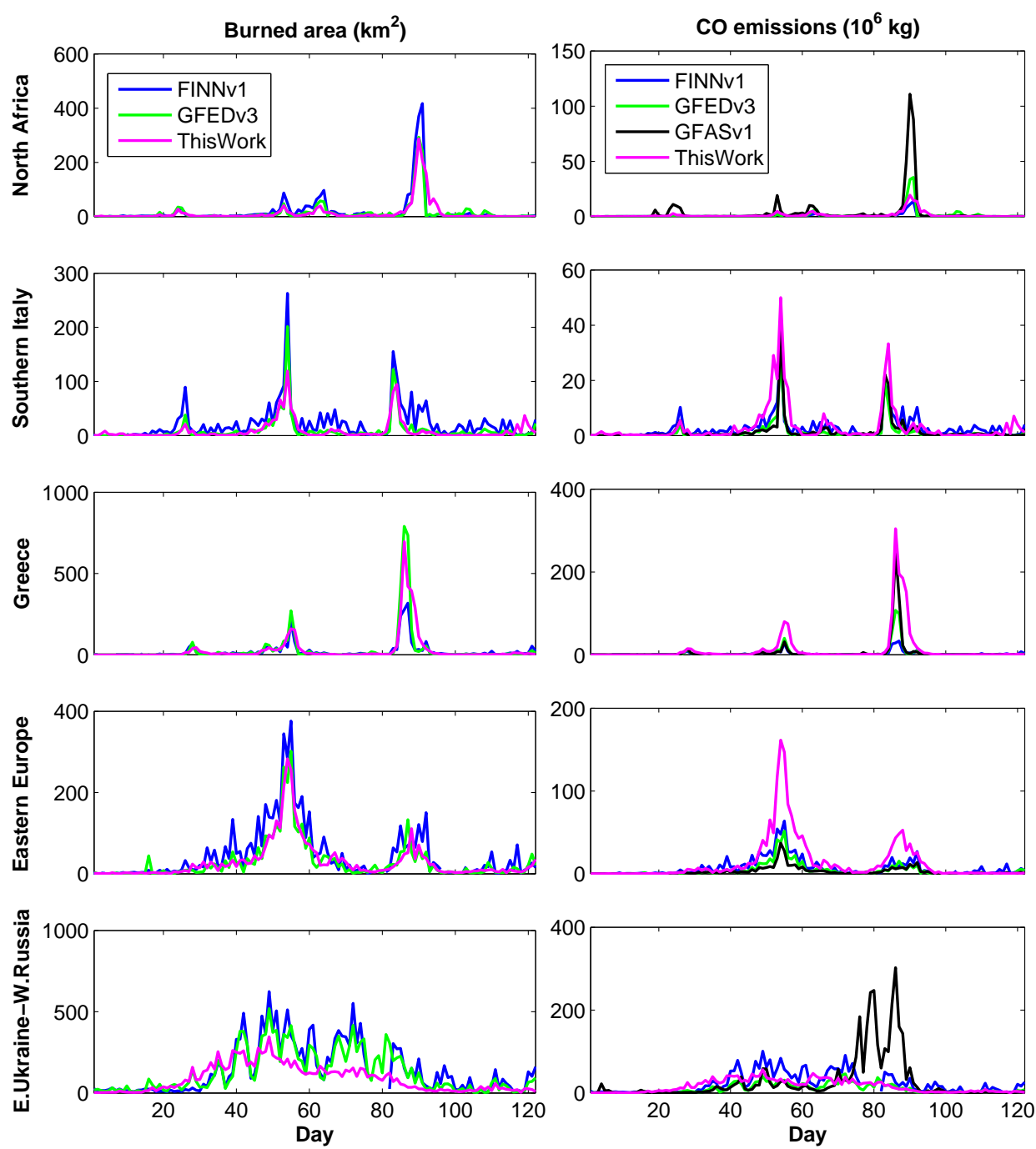

Fig. 9. Daily burned area (left) and carbon monoxide (CO) emissions (right) during the summer of 2007 within subregions of Fig. 3 according to the present work and the FINNv1 and GFEDv3 inventories. Day 1 corresponds to 1 June, and day 120 to 30 September. Details on each inventory's specifications are provided in Table 6.

FINN estimate, and $14 \%$ lower than the GFED estimate, but regional differences can reach very large values if the fire activity is temporally shifted, like in Greece where the large event in August lasts one day longer in our estimate based on the MCD64 product.

Although GFEDv3 uses the same burned area product as the one used in this work for the monthly total, the daily variability is derived from the active fires product. Some events therefore do not have the exact same timing. The largest discrepancies are obtained over the eastern regions: Ukraine, western Russia and Turkey, where GFEDv3 is significantly larger. This may be due to the weighting of the pixel size by the vegetated fraction used here.

The corresponding CO emissions, shown in Fig. 9, show significantly larger differences (daily regional emissions 2.5 times larger than GFED and GFAS on average, $70 \%$ larger than FINN). One of the reasons for the difference in emissions may be the use of different vegetation attributions. This will imply differences in emission factors. In GFED and GFAS, the $\mathrm{CO}$ emission factor used for extra-tropical forests is equal to $106 \mathrm{~g} \mathrm{~kg}^{-1}$, while it is equal to only $89 \mathrm{~g} \mathrm{~kg}^{-1}$ in APIFLAME. Burning more forest types would then result in larger emissions in GFEDv3 and GFASv1. On the contrary, the emission factor for cropland burning is larger in the APIFLAME inventory. However, similar differences between the inventories are obtained when comparing carbon emissions (i.e., fuel consumption, before any emission factor is applied) with GFEDv3 (daily regional values on average 5 times larger for this work) (Fig. 11). If the global ORCHIDEE simulation is used instead of the regional one, results are only slightly lower. However, using a different vegetation database significantly decreases carbon emissions. The 
Table 8. Average (2003-2012) total annual emissions in Gg for different pollutants and regions of the Euro-Mediterranean (EuroMediterranean: latitudes between 36 and $48^{\circ} \mathrm{N}$, divided into 3 subdomains: West from $10^{\circ} \mathrm{W}$ to $5^{\circ} \mathrm{E}$, Central from 5 to $20^{\circ} \mathrm{E}$, and East from 20 to $35^{\circ}$ E.). The average total emissions from the GFED and GFAS inventories are provided for comparison (total within the EuroMediterranean domain).

\begin{tabular}{lrrrrrr}
\hline Species & Western Eu. & Central Eu. & Eastern Eu. & Euro-Med. & GFED $^{\mathrm{a}}$ & GFAS \\
\hline $\mathrm{CO}$ & 1013 & 404 & 1164 & 2581 & 696 & 1376 \\
$\mathrm{NO}_{\mathrm{X}}$ & 40 & 15 & 39 & 94 & 24 & 43 \\
$\mathrm{NMVOCs}$ & 182 & 76 & 231 & 489 & 68 & 455 \\
$\mathrm{NH}_{3}$ & 15 & 6 & 21 & 42 & 66 & 19 \\
$\mathrm{SO}_{2}$ & 8 & 3 & 7 & 18 & 6 & 8 \\
$\mathrm{OC}_{\mathrm{BC}}$ & 58 & 20 & 40 & 118 & 48 & 76 \\
$\mathrm{TPM}$ & 11 & 4 & 9 & 24 & 5 & 9 \\
\hline
\end{tabular}

a Average for years 2003-2010 for the GFED inventory; ${ }^{b}$ NMHC in the GFED inventory.

Table 9. Average (2003-2011) total annual emissions in Gg by country for the main pollutants, for the fire emissions (F) and the EMEP anthropogenic emissions (A). Only countries for which fire CO emissions are larger than $30 \mathrm{Gg} \mathrm{yr}^{-1}$ on average, and for which anthropogenic emissions are available in the EMEP inventory, are reported.

\begin{tabular}{|c|c|c|c|c|c|c|c|c|c|c|c|c|c|c|}
\hline \multirow[b]{2}{*}{ Country } & \multicolumn{2}{|c|}{$\mathrm{CO}$} & \multicolumn{2}{|c|}{$\mathrm{NO}_{\mathrm{X}}$} & \multicolumn{2}{|c|}{ NMVOCs } & \multicolumn{2}{|c|}{$\mathrm{NH}_{3}$} & \multicolumn{2}{|c|}{$\mathrm{SO}_{2}$} & \multicolumn{2}{|c|}{$\mathrm{PM}_{2.5}$} & \multicolumn{2}{|c|}{ PM coarse* } \\
\hline & $\mathrm{F}$ & A & $\mathrm{F}$ & $\mathrm{A}$ & $\mathrm{F}$ & A & $\mathrm{F}$ & A & $\mathrm{F}$ & A & $\mathrm{F}$ & A & $\mathrm{F}$ & A \\
\hline Albania & 100 & 128 & 3 & 26 & 17 & 30 & 2 & 25 & 1 & 35 & 13 & 13 & 2 & 4 \\
\hline Bulgaria & 65 & 315 & 2 & 139 & 13 & 88 & 1 & 56 & 0.4 & 654 & 6 & 30 & 1 & 21 \\
\hline Bosnia-Herzegovina & 75 & 116 & 3 & 52 & 13 & 42 & 1 & 17 & 0.7 & 429 & 10 & 19 & 2 & 25 \\
\hline Spain & 294 & 1997 & 12 & 1133 & 53 & 752 & 4 & 373 & 3 & 902 & 39 & 85 & 8 & 38 \\
\hline France & 40 & 4634 & 2 & 1269 & 7 & 1059 & 1 & 661 & 0.3 & 382 & 5 & 274 & 1 & 117 \\
\hline Greece & 186 & 666 & 7 & 382 & 35 & 219 & 3 & 66 & 1 & 456 & 21 & 57 & 3 & 33 \\
\hline Croatia & 17 & 326 & 1 & 78 & 3 & 94 & 0.2 & 39 & 0.1 & 57 & 2 & 11 & 0.5 & 5 \\
\hline Italy & 156 & 3160 & 6 & 1113 & 30 & 1223 & 2 & 408 & 1 & 338 & 15 & 167 & 2 & 30 \\
\hline Republic of Moldova & 38 & 126 & 1 & 30 & 8 & 35 & 1 & 26 & 0.1 & 12 & 2 & 6 & 0.01 & 3 \\
\hline Macedonia & 41 & 95 & 1 & 36 & 7 & 28 & 1 & 9 & 0.3 & 105 & 5 & 9 & 1 & 9 \\
\hline Portugal & 700 & 513 & 28 & 224 & 125 & 198 & 11 & 49 & 6 & 126 & 91 & 58 & 17 & 25 \\
\hline Romania & 66 & 1264 & 2 & 300 & 13 & 441 & 1 & 185 & 0.3 & 584 & 5 & 110 & 0.4 & 28 \\
\hline Ukraine & 1727 & 2817 & 53 & 592 & 357 & 338 & 36 & 179 & 7 & 1279 & 107 & 228 & 1 & 162 \\
\hline Turkey & 573 & 3549 & 20 & 1122 & 115 & 1080 & 10 & 431 & 3 & 1551 & 44 & 256 & 5 & 99 \\
\hline Total & 4077 & 19708 & 141 & 6497 & 799 & 5627 & 74 & 2524 & 23 & 6910 & 367 & 1322 & 44 & 600 \\
\hline
\end{tabular}

* TPM-PM 2.5 in fire inventory.

critical parameter is thus the methodology used for the fuel load and consumption estimation in the different inventories.

Vegetation attribution may also explain some of the differences in the fuel load consumption differences among inventories. Since the fuel load consumed is larger in forest and cropland vegetation types, the carbon emissions are expected to be higher if more fires are attributed to vegetation types including carbon from forest and agriculture PFTs (forests, shrubland, woodland, cropland). As already mentioned in the previous section, regions with the largest differences in carbon amounts also often correspond to regions with the largest differences in vegetation attribution. In eastern Europe during the summer of 2007 for example, the carbon emissions calculated by the APIFLAME inventory with CLC vegetation correspond to $67 \%$ forest and shrubland, while this fraction is equal to $39 \%$ with the MODIS vegetation and $49 \%$ in GFEDv3. In Greece, the fraction of carbon emissions in the APIFLAME inventory for forest and shrubland is equal to $62 \%$ with CLC, while it is $45 \%$ with the MODIS vegetation. However, this fraction is equal to $79 \%$ for GFEDv3, indicating that the vegetation mapping is not the only issue. For the full Euro-Mediterranean region, forest, woodland and shrubland account for $37 \%$ of the carbon emissions in the APIFLAME inventory with CLC, $20 \%$ of the emissions with MOD12, and $53 \%$ of the emissions in GFEDv3. Cropland burning accounts for $56 \%$ of the carbon emissions in APIFLAME with CLC, $72 \%$ with MOD12, and $41 \%$ in GFEDv3.

In their analysis of the impact of fires on air quality, Hodnebrog et al. (2012) included the FINNv1 and GFEDv2 


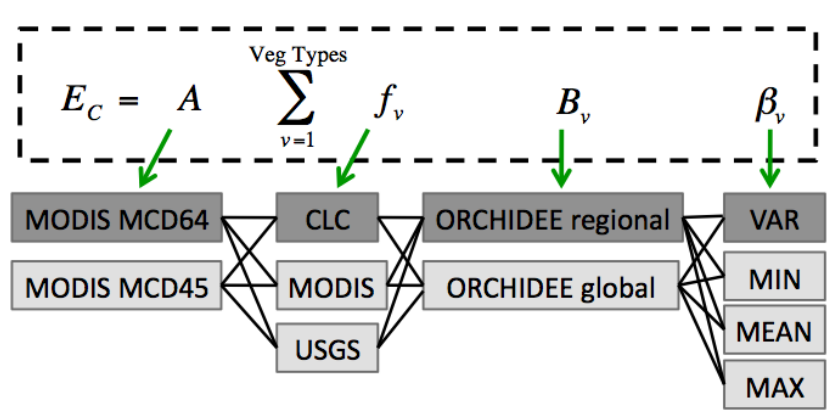

Fig. 10. Schematic representation of the 48 configurations used for the ensemble calculation of carbon emissions. The 4 scenarios for the fraction of biomass available for burning $\beta$ are minimum efficiency (MIN), maximum (MAX), average (MEAN) and varying depending on moisture stress (VAR). The dark gray boxes correspond to the default options for each of the parameters.

inventories in chemistry-transport models and conducted comparisons to satellite observations of plumes from fires in Greece. They have shown that $\mathrm{CO}$ emissions are significantly underestimated in both inventories, resulting in concentrations up to one order of magnitude too low. Although more in depth evaluation against observations is required, the larger emissions in this new regional methodology appear to be in better agreement with the trace gas observations analyzed by Hodnebrog et al. (2012).

\subsection{Ensemble approach}

Different databases may be used to estimate the key parameters of Eq. (1) controlling emissions estimates. Intercomparing these options shows that significant uncertainty is associated with each of these parameters. However, quantifying the individual uncertainties does not provide a reliable estimate of the resulting uncertainty regarding emissions. For example, for a given burned area in a given region, if the location varies by a few kilometers between fire observation sources, then a different vegetation burned may be attributed, as well as a different fuel consumption, resulting in different emissions.

In this study, we have chosen to calculate an ensemble of emissions for the case of the summer of 2007, using different options for each of the parameters of Eq. (1). Since fuel consumed has been identified as one of the main sources of discrepancies between various emission models, the analysis is focused on the carbon emissions, before any application of emission factors. 48 calculations were performed, changing one parameter at a time, as shown in Fig. 10. The dark shaded boxes highlight the reference setup of the emissions model: MCD64 area burned product, the CLC vegetation type and the regional ORCHIDEE simulation with the fraction available for burning depending on moisture stress (VAR).

Although these options are not always fully independent (hence minimizing uncertainties), they allow a first evaluation of the uncertainties in the model calculations and of their sensitivity to various options.

The results in terms of daily carbon emissions (or fuel consumption) within the main burning subregions are shown in Fig. 11. The emission profiles for the reference configuration and the reference configuration with different vegetation maps are shown along with the GFED carbon emissions for comparison.

The range of possible daily emissions appears to be extremely large. The total emitted carbon during July-August in the Euro-Mediterranean region varies between 12 and $63 \mathrm{Tg}$, with an ensemble average at $30 \mathrm{Tg}$. The reference inventory gives a total of $42 \mathrm{Tg}$ with the CLC vegetation database, and twice lower with the MODIS vegetation database. GFED indicates a total of $10 \mathrm{Tg}$ emitted. Smallest values of the ensemble are usually obtained when the global ORCHIDEE simulation is used for biomass density with the MODIS vegetation database. Note that the ORCHIDEE simulations were performed with the CLC land cover, so that better consistency is expected and may explain some of these differences.

The standard deviation of the ensemble members is $53 \%$ on average for the daily emissions within the region, and varies between 50 and $84 \%$ for the six subregions considered here (Fig. 11). In most regions, the reference inventory, using CLC, results in the highest values, while calculations based on the MODIS or USGS land covers are closer to the ensemble average and the GFED estimates. Some large peaks in the ensemble calculations are absent from the reference calculations. These are associated with large areas burned in the MCD45 area burned product that are not in the MCD64 product. A strong variability is thus related to the choice of area burned or vegetation types.

For a more precise quantification of the uncertainties, the standard deviation of the ensemble members for calculations on a $25 \mathrm{~km}$ resolution grid is analyzed grid cell by grid cell. The cumulative frequency distribution is presented in Fig. 12. The standard deviations associated with sub-ensembles, with only one varying parameter at a time, are also shown. The full ensemble has a standard deviation of $93 \%$ on average, relative to the ensemble mean. It is larger than $100 \%$ for $\sim 50 \%$ of the cases. The sub-ensemble with only area burned varying gives larger dispersions, with standard deviations of $103 \%$ on average, and larger than $\sim 140 \%$ for $\sim 50 \%$ of the cases. The dispersion of this sub-ensemble is on average larger than that of the full ensemble, indicating error compensations. The second largest dispersion comes from the vegetation database used, with an average standard deviation of $44 \%$. In this analysis, the lowest uncertainty is associated with the fuel consumption, with a standard deviation of $14 \%$ on average if either one of the ORCHIDEE simulations is used, and of only $4 \%$ for the different scenarios of combustion completeness. This low sensitivity to the different scenarios is due to the large fraction of fires in grassland and cropland, for which the scenario does not have a significant 


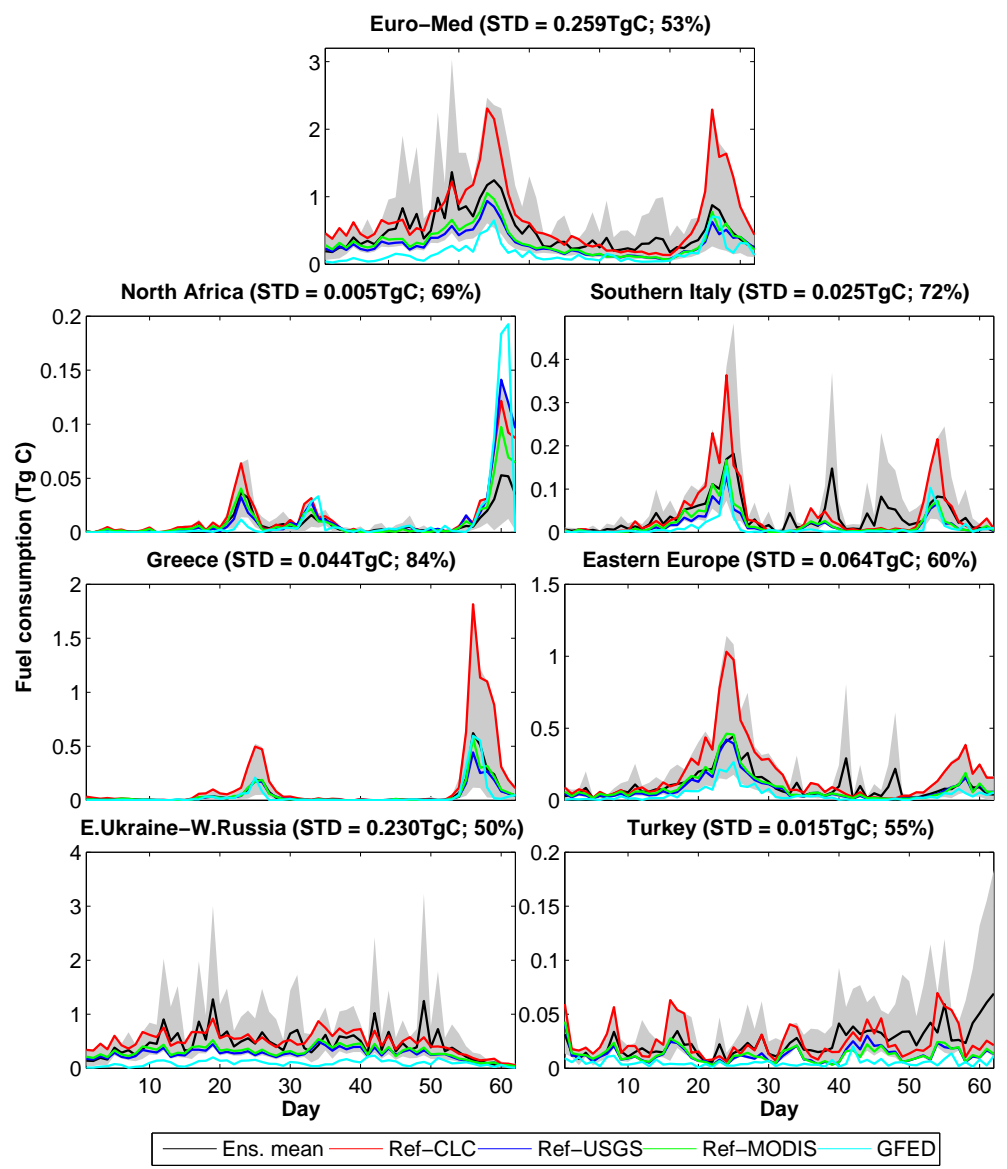

Fig. 11. Daily fuel consumption for the ensemble mean, and the reference configuration and either CLC, MODIS or USGS landcover types for July-August 2007. The spread of the ensemble is indicated by the shaded gray area. The values from the GFED inventory are also plotted for comparison. The average standard deviation (absolute value and relative to the ensemble mean) is indicated on top of each plot.

impact (cf. Sect. 5.1). This analysis very likely underestimates the uncertainty associated with fuel loading since only one model (although in different configurations) is used here for biomass density. Comparison with other inventories has shown that fuel load is a critical parameter. This contribution to ensemble uncertainty should be analyzed using different carbon cycle models.

Using a Monte Carlo approach, van der Werf et al. (2010) evaluated the uncertainty regarding the average annual global GFED carbon emissions to $20 \%$. For their analysis, they assumed uncertainties regarding biomass density of 44 and $22 \%$ for grassland and forest, respectively, as well as uncertainties regarding area burned (values provided by Giglio et al. (2010), equal to $\sim 10 \%$ in the Northern Hemisphere), but this estimate does not include the impact of uncertainties regarding the land use assumed to have burned (vegetation mapping). These values are lower for different reasons. Firstly, these uncertainties are estimated on annual totals, which lowers uncertainties compared to daily or monthly totals. Secondly, the uncertainties regarding each parameter are lower than those used in this work. Thirdly, the uncertainties van der Werf et al. (2010) attributed to each of the GFED emission model parameters were lower than those assumed in our study.

Urbanski et al. (2011) also used a Monte Carlo approach to analyze uncertainties regarding regional emissions in the western US, but worked at different spatial and temporal scales. On an annual and region-wide scale, they estimate that their uncertainty regarding fuel consumption ranges from 19 to $47 \%$, and that that regarding $\mathrm{CO}$ emissions ranges from 28 to $51 \%$. They show that uncertainty significantly increases at lower temporal and spatial scales. At daily and kilometric (up to $\sim 1 \mathrm{~km}$ ) resolutions, they find uncertainties larger than $133 \%$ for more than $50 \%$ of the CO emissions. At these scales, they find that uncertainty is mainly driven by uncertainties in the burned area. These values are slightly larger but consistent with our results from the ensemble. None of the previous studies addressed the impact of vegetation mapping and attribution in the final uncertainty, but we show that it is also an important factor.

More generally, Wiedinmyer et al. (2011) evaluate the uncertainty regarding daily emissions to a factor of 2 based on a 


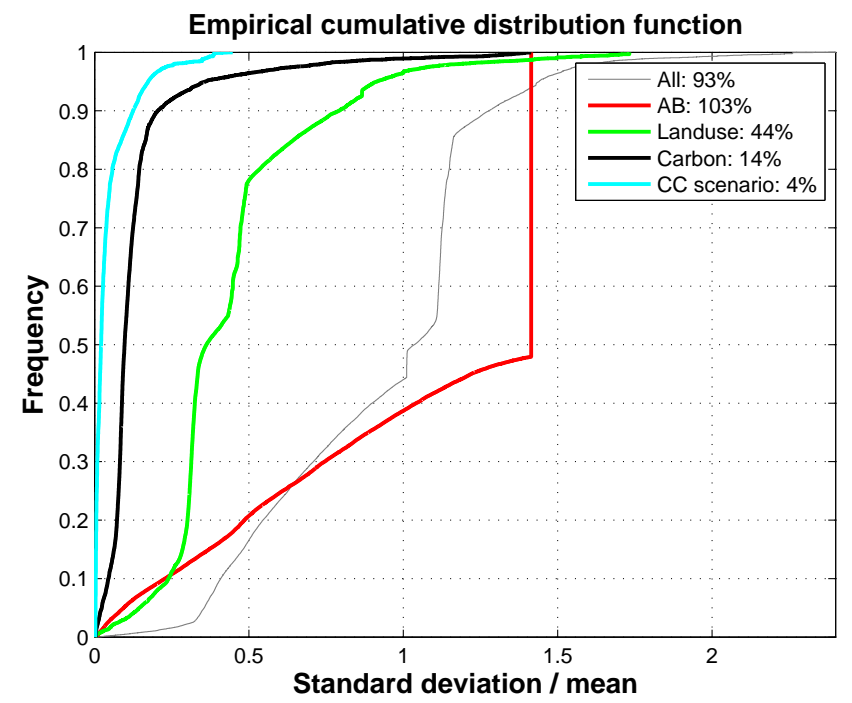

Fig. 12. Cumulative density functions (CDF) of the standard deviation of the ensemble results for daily emissions (relative to the ensemble average). CDF for the 48 estimates is indicated in gray. The CDFs for calculations with the reference configuration and one varying parameter are also indicated, with the following parameters considered individually: area burned $(\mathrm{AB})$, vegetation database (landuse), biomass density (carbon), scenario of combustion completeness (CC scenario). The numbers in the caption correspond to the average of the standard deviations (scaled by the mean values) for each ensemble set.

qualitative analysis of uncertainties regarding each parameter provided in the literature. This factor of 2 is consistent with the results of both the ensemble and the intercomparison.

Although peat burning is not a major issue in the EuroMediterranean region, it becomes important in northern and eastern Europe and in Russia. As detailed in Sect. 5.1, the fuel load consumed depends on the depth of burning and the dryness of the available fuel. Available observations show a strong variation across regions and time of fire season, from $6.8 \mathrm{~kg} \mathrm{DMm}^{-2}$ (early season fire in boreal regions) to $48.75 \mathrm{~kg} \mathrm{DMm}^{-2}$ (Indonesia) in the values used here, hence showing a spread of more than a factor of 7 in fuel consumed only.

\section{Code structure and availability}

Source code for the emission model may be obtained from the following web page: http://www.lmd.polytechnique.fr/ apiflame.

The model has been written to allow full flexibility in terms of:

- species accounted for: any species may be included provided its emission factor is known;

- region analyzed: any domain may be chosen since global databases are provided;
- fire information: any list of fire location, date of burning and associated area burned may be used.

Several vegetation databases are provided (CLC, MODIS, USGS), but adding a new vegetation database only requires the addition of associated correspondence matrices between the vegetation classes, the ORCHIDEE PFT types and the vegetation types for which emission factors are provided.

All user specifications are informed in the main script. The code then calculates emission inventories in two steps (two executables):

1. Calculation of emissions for each detected fire pixel, and for inventory species; write output ascii file (required input: list of fire location, date and associated burned area);

2. Aggregation to model species and model grid; write output netcdf file (required input: output from step 1).

The simulation may be limited to the first step.

\section{Conclusions}

Emissions of trace gases and aerosols from wildfires represent one of the most important sources of pollutants in many regions of the globe. In this paper, a new model (APIFLAME emission model v1.0) for this source in chemistry-transport models is presented. It has been developed to meet the specific needs of air quality monitoring, namely the calculation of the emissions for the main atmospheric pollutants, at high horizontal and time resolution, with flexibility in terms of domain and species emitted. We presented a specific application to the Euro-Mediterranean area.

An analysis of fire activity in this region has been undertaken using the MODIS MCD64 area burned and MOD14 active fire products. The fire season extends from June to October in most areas, with some burning in spring in the eastern part of the region, but the most intense fires and largest areas burned occur in summer (July and August). Yearly burned areas are consistent with the forest fire reports from EFFIS/JRC (within 20-30\%) in most countries, but are significantly larger in eastern Europe and Turkey. This is probably due to the fact that agricultural fires are not reported in the forest fires database. Fires affect extended regions in eastern Europe, Ukraine and western Russia with high frequency (every year in some regions), but with small durations and small burned areas on average, indicating many small fires. In the southern countries (Portugal and the Mediterranean areas), fires are less frequent, very localized, but can last 5-10 days with large burned areas. Both types of fires (large events for several days or smaller recurrent fires) have a potentially large impact on regional pollution budgets that needs to be accounted for, especially during summer. A large fraction of the burned area detected appears in agricultural areas (about half of the detected fires), followed by forests $(\sim 21 \%)$, 
grasslands $(\sim 21 \%)$, and shrublands $(\sim 9 \%)$. Agricultural fires are particularly frequent in the eastern regions.

Fire emissions are calculated using the classical approach introduced by Seiler and Crutzen (1980) and used in many inventories. They are derived by multiplying the area burned by the amount of fuel available, combustion completeness, and the emission factors of each included species. Since fuel load and emission factors both depend on the type of vegetation burned, precise knowledge of this parameter is essential for obtaining accurate emission estimates. The model allows the use of several databases. For Europe, the CORINE landcover database (CLC), regridded at $1 \mathrm{~km}$ resolution, is recommended. The MODIS MCD12Q1 database $(500 \mathrm{~m}$ resolution) is used as a default outside of the CLC domain. Land use (input data) may be modified according to specific applications without modification of the model's core.

The fuel load is derived from simulations by the ORCHIDEE model and depends on the vegetation burned and its location. Monthly mean outputs from global and regional simulations (over Europe) are provided, at 70 and $30 \mathrm{~km}$ resolution, respectively. The fuel load in terms of carbon available to burning is estimated depending on the type of vegetation burned, its location, the date of burning, as well as the fuel moisture stress.

Emissions factors (g species per kg dry matter burned) then allow the calculation of emissions for a series of trace gases and aerosols. The emissions for inventory species are converted to emissions for model species adapted to specific chemical schemes included in chemistry-transport models using an aggregation matrix. These are provided as input and can be modified by users. Finally, emissions can be gridded within a user-specified model grid (domain and resolution).

The regional emissions for the 2003-2012 time period are discussed using the default configuration of the APIFLAME emission model: MODIS MCD64 area burned, CLC vegetation classification, regional ORCHIDEE simulation, and fuel load calculation depending on moisture stress. Fires represent a significant additional pollution source in the region, corresponding, for example, to $21 \%$ of the annual anthropogenic emissions for $\mathrm{CO}, 28 \%$ for $\mathrm{PM}_{2.5}$, but mostly concentrated during the summer. On average over the past $10 \mathrm{yr}$, the countries most affected have been Portugal (CO emissions from fires amounting to $156 \%$ of anthropogenic emissions), the Balkan Peninsula, Moldova, Ukraine and Spain. Comparison of the CO emissions with emissions from several widely used inventories (GFEDv3, GFASv1, FINNv1) shows good correlations, highlighting the good consistency in spatial and temporal variability across the selected methodologies. However, the emitted mass is significantly larger, by a factor of 2.5 compared to GFEDv3 and GFASv1 on average over the whole region. Emissions are particularly large compared to other inventories in eastern Europe, Ukraine, western Russia and Turkey. These discrepancies are likely attributable to uncertainties in the fuel load estimates.
A more detailed analysis of the summer of 2007, which was characterized by strong burning in eastern Europe and the Mediterranean area, has been undertaken. An ensemble of calculations relying on the various options allowed by the emissions model has been used in order to evaluate the uncertainty regarding emissions associated with each parameter of the equation.

The standard deviation of the emissions among the different members of the ensemble shows that uncertainty is close to $100 \%$ in the daily carbon emissions, with the dominant contribution from uncertainties in the area burned, and a significant contribution from the vegetation map used $(\sim 44 \%)$. This source of uncertainty had not been considered independently in previous uncertainty analyses based on a Monte Carlo approach. Urbanski et al. (2011) evaluated the impact of different fuel loading databases, implicitly including vegetation type, and van der Werf et al. (2010) considered uncertainty in the fuel load values but not in the vegetation mapping. In our study, uncertainty in the biomass density and fuel load calculation method is low but probably underestimated due to the fact that the same carbon cycle model is used (ORCHIDEE). Uncertainty in total daily emissions within the main burning subregions is estimated at $\sim 50$ $84 \%$. Carbon emissions from the GFEDv3 inventories are within the ensemble, but generally closer to the smallest values. In addition to these large uncertainties in carbon emissions, uncertainties in emission factors must be considered for trace gas and particulate matter emissions, explaining the larger differences among inventories (a factor of 2-3).

Our analysis of the active fire observations from the MSG/SEVIRI instrument suggests that fire activity is more intense during the afternoon. However, some regions show a larger number and intensity of fires at night (southern Italy). It is therefore difficult to derive an averaged climatological diurnal profile representative of all fires in the region. The emissions model allows the use of a mean diurnal profile. A future version of the algorithm will include diurnal variations from coincident SEVIRI observations for a more accurate representation of each fire's specificities.

Future developments will also include a parameterization of ground layer burning and peatland fires, to allow applications to boreal regions in particular.

The APIFLAME model may be applied to the analysis of past events or to the near-real time monitoring of emissions, provided area burned data are available. Daily emissions at a $0.25^{\circ} \times 0.25^{\circ}$ resolution for the 2003-2012 time period over Europe may be obtained from the CHARMEX (ChemistryAerosol Mediterranean Experiment) project page of the ECCAD database (http://eccad.pole-ether.fr).

Acknowledgements. This work was undertaken in the framework of the APIFLAME project, supported by French research program PRIMEQUAL (project no. 0962C0068), and the APPAD project funded by DGA. The French Ministry in charge of ecology is also acknowledged. The authors thank ECCAD and the CHARMEX 
project for including the inventory within the database. We are also grateful to the MODIS land data teams and NASA LPDAAC for data availability, as well as Louis Giglio for his help using the MODIS fire data. We also wish to thank Christine Wiedinmyer, Guido van der Werf and Johannes Kaiser for the availability of their inventories and for helpful discussions. Alexander Chernokulsky and Alla Yurova are acknowledged for their help preparing the mire mask for Eurasia. Finally, the authors also thank the two anonymous reviewers of this manuscript for their helpful comments and corrections.

Edited by: P. Jöckel

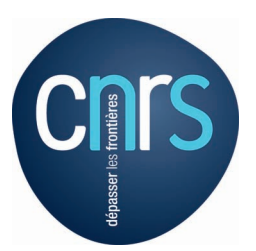

The publication of this article is financed by CNRS-INSU.

\section{References}

Akagi, S. K., Yokelson, R. J., Wiedinmyer, C., Alvarado, M. J., Reid, J. S., Karl, T., Crounse, J. D., and Wennberg, P. O.: Emission factors for open and domestic biomass burning for use in atmospheric models, Atmos. Chem. Phys., 11, 4039-4072, doi:10.5194/acp-11-4039-2011, 2011.

Alves, C., Gonçalves, C., Pio, C., Mirante, F., Caseiro, A., Tarelho, L., Freitas, M., and Viegas, D.: Smoke emissions from biomass burning in a Mediterranean shrubland, Atmos. Environ., 44, 3024-3033, doi:10.1016/j.atmosenv.2010.05.010, 2010.

Alves, C., Vicente, A., Nunes, T., Gonçalves, C., Fernandes, A., Mirante, F., Tarelho, L., Sanchez de la Campa, A., Querol, X., Caseiro, A., Monteiro, C., Evtyugina, M., and Pio, C.: Summer 2009 wildfires in Portugal: emission of trace gases and aerosol composition, Atmos. Environ., 45, 641-649, doi:10.1016/j.atmosenv.2010.10.031, 2011.

Amiridis, V., Giannakaki, E., Balis, D. S., Gerasopoulos, E., Pytharoulis, I., Zanis, P., Kazadzis, S., Melas, D., and Zerefos, C.: Smoke injection heights from agricultural burning in Eastern Europe as seen by CALIPSO, Atmos. Chem. Phys., 10, 11567-11576, doi:10.5194/acp-10-11567-2010, 2010.

Anav, A., D'Andrea, F., Viovy, N., and Vuichard, N.: A validation of heat and carbon fluxes from high resolution land surface and regional models, J. Geophys. Res., 115, G04016, doi:10.1029/2009JG001178, 2010.

Andreae, M. O. and Merlet, P.: Emission of trace gases and aerosols from biomass burning, Global Biogeochem. Cy., 15, 995-966, doi:10.1029/2000GB001382, 2001.

Andreae, M. O., Rosenfeld, D., Artaxo, A., Costa, A. A., Frank, G. P., Longo, K. M., and Silva-Dias, M. A. F.: Smoking rain clouds over the Amazon, Science, 303, 1337-1342, doi:10.1126/science.1092779, 2004.

Bartalev, S. A., Belward, A. S., Erchov, D. V., and Isaev, A. S.: A new SPOT4VEGETATION derived land cover map of Northern Eurasia, Int. J. Remote Sens., 24, 1977-1982, doi:10.1080/0143116031000066297, 2003.
Berrisford, P., Dee, D., Fielding, K., Fuentes, M., Kallberg, P., Kobayashi, S., and Uppala, S.: The ERA-Interim archive, ERA40 Report Series No. 1, Tech. rep., ECMWF, Shinfield Park, Reading, 2009.

Davies, G. M., Gray, A., Rein, G., and Legg, C. J.: Peat consumption and carbon loss due to smouldering wildfire in a temperate peatland, Forest Ecol. Manage., 308, 169-177, doi:10.1016/j.foreco.2013.07.051, 2013.

EC: 2008 Directive 2008/50/EC of the European Parliament and of the council of 21 May 2008 on ambient air quality and cleaner air for Europe, European Parliament, Council, Official Journal L 152, 0001-0044, 2008.

EEA: Technical report No17, CLC2006 technical guidelines, Tech. rep., European Environment Agency, Office for Official Publications of the European Communities, Copenhagen, 2007.

Freeborn, P., Wooster, M., Hao, W., Ryan, C., Nordgren, B., Baker, S., and Ichoku, C.: Relationships between energy release, fuel mass loss, and trace gas and aerosol emissions during laboratory biomass fires, J. Geophys. Res., 113, D01301, doi:10.1029/2007JD008489, 2008.

Friedl, M. A., Sulla-Menashe, D., Tan, B., Schneider, A., Ramankutty, N., Sibley, A., and Huang, X.: MODIS collection 5 global land cover: algorithm refinements and characterization of new datasets, Remote Sens. Environ., 114, 168-182, doi:10.1016/j.rse.2009.08.016, 2010.

Gibbs, H.: Olson's major world ecosystem complexes ranked by carbon in live vegetation: an updated database using the GLC 2000 land cover product, available at: http://cdiac.ornl.gov/ epubs/ndp/ndp017/ndp017b.html (last access: 31 October 2013), 2006.

Giglio, L., Csiszar, I., and Justice, C. O.: Global distribution and seasonality of active fires as observed with the terra and aqua MODIS sensors, J. Geophys. Res., 111, G02016, doi:10.1029/2005JG000142, 2006.

Giglio, L., Randerson, J. T., van der Werf, G. R., Kasibhatla, P. S., Collatz, G. J., Morton, D. C., and DeFries, R. S.: Assessing variability and long-term trends in burned area by merging multiple satellite fire products, Biogeosciences, 7, 1171-1186, doi:10.5194/bg-7-1171-2010, 2010.

Grell, G., Freitas, S. R., Stuefer, M., and Fast, J.: Inclusion of biomass burning in WRF-Chem: impact of wildfires on weather forecasts, Atmos. Chem. Phys., 11, 5289-5303, doi:10.5194/acp11-5289-2011, 2011.

Hansen, M. C., DeFries, R. S., Townshend, J. R. G., Carroll, M., Dimiceli, C., and Sohlberg, R. A.: Global percent tree cover at a spatial resolution of 500 meters: first results of the MODIS vegetation continuous fields algorithm, Earth Interact., 7, 1-15, doi:10.1175/1087-3562(2003)007<0001:GPTCAA>2.0.CO;2, 2003.

Hodnebrog, Ø., Solberg, S., Stordal, F., Svendby, T. M., Simpson, D., Gauss, M., Hilboll, A., Pfister, G. G., Turquety, S., Richter, A., Burrows, J. P., and Denier van der Gon, H. A. C.: Impact of forest fires, biogenic emissions and high temperatures on the elevated Eastern Mediterranean ozone levels during the hot summer of 2007, Atmos. Chem. Phys., 12, 8727-8750, doi:10.5194/acp-12-8727-2012, 2012.

Hodzic, A., Madronich, S., Bohn, B., Massie, S., Menut, L., and Wiedinmyer, C.: Wildfire particulate matter in Europe during summer 2003: meso-scale modeling of smoke emissions, trans- 
port and radiative effects, Atmos. Chem. Phys., 7, 4043-4064, doi:10.5194/acp-7-4043-2007, 2007.

Hoelzemann, J. J., Schultz, M. G., Brasseur, G. P., Granier, C., and Simon, M.: Global Wildland Fire Emission Model (GWEM): evaluating the use of global area burnt satellite data, J. Geophys. Res., 109, D14S04, doi:10.1029/2003JD003666, 2004.

Hyer, E. J. and Reid, J. S.: Baseline uncertainties in biomass burning emission models resulting from spatial error in satellite active fire location data, Geophys. Res. Lett., 36, L05802, doi:10.1029/2008GL036767, 2009.

Jacob, D. and Podzun, R.: Sensitivity studies with the Regional Climate Model REMO, Meteorol. Atmos. Phys., 63, 119-129, 1997.

Jaffe, D. A. and Wigder, N. L.: Ozone production from wildfires: a critical review, Atmos. Environ., 51, 1-10, doi:10.1016/j.atmosenv.2011.11.063, 2012.

Jaffe, D., Hafner, W., Chand, D., Westerling, A., and Spracklen, D.: Inter-annual variations in $\mathrm{PM}_{2.5}$ due to wildfires in the Western United States, Environ. Sci. Technol., 42, 2812-2818, doi:10.1021/es702755v, 2008.

Kaiser, J. W., Heil, A., Andreae, M. O., Benedetti, A., Chubarova, N., Jones, L., Morcrette, J.-J., Razinger, M., Schultz, M. G., Suttie, M., and van der Werf, G. R.: Biomass burning emissions estimated with a global fire assimilation system based on observed fire radiative power, Biogeosciences, 9 , 527-554, doi:10.5194/bg-9-527-2012, 2012.

Konovalov, I. B., Beekmann, M., Kuznetsova, I. N., Yurova, A., and Zvyagintsev, A. M.: Atmospheric impacts of the 2010 Russian wildfires: integrating modelling and measurements of an extreme air pollution episode in the Moscow region, Atmos. Chem. Phys., 11, 10031-10056, doi:10.5194/acp-11-10031-2011, 2011.

Koren, I., Kaufman, Y. R., Remer, L. A., and Martins, J. V.: Measurement of the effect of Amazon smoke on inhibition of cloud formation, Science, 303, 1342-1345, doi:10.1126/science.1089424, 2004.

Krinner, G., Viovy, N., de Noblet-Ducoudré, N., Ogée, J., Polcher, J., Friedlingstein, P., Ciais, P., Sitch, S., and Prentice, I. C.: A dynamic global vegetation model for studies of the coupled atmosphere-biosphere system, Global Biogeochem. Cy., 19, GB1015, doi:10.1029/2003GB002199, 2005.

Langmann, B., Duncan, B., Textor, C., Trentmann, J., and van der Werf, G.: Vegetation fire emissions and their impact on air pollution and climate, Atmos. Environ., 43, 107-116, doi:10.1016/j.atmosenv.2008.09.047, 2009.

Levine, J. S.: The 1997 fires in Kalimantan and Sumatra, Indonesia: Gaseous and particulate emissions, Geophys. Res. Lett., 26, 815818, doi:10.1029/1999GL900067, 1999.

Li, F., Zeng, X. D., and Levis, S.: A process-based fire parameterization of intermediate complexity in a Dynamic Global Vegetation Model, Biogeosciences, 9, 2761-2780, doi:10.5194/bg-9-27612012, 2012.

Maignan, F., Bréon, F.-M., Chevallier, F., Viovy, N., Ciais, P., Garrec, C., Trules, J., and Mancip, M.: Evaluation of a Global Vegetation Model using time series of satellite vegetation indices, Geosci. Model Dev., 4, 1103-1114, doi:10.5194/gmd-4-11032011, 2011.

Mieville, A., Granier, C., Liousse, C., Guillaume, B., Mouillot, F., Lamarque, J.-F., Grégoire, J.-M., and Pétron, G.: Emissions of gases and particles from biomass burning during the 20th century using satellite data and an historical reconstruction, Atmos. Environ., 44, 1469-1477, doi:10.1016/j.atmosenv.2010.01.011, 2010.

Mouillot, F. and Field, C.: Fire history and the global carbon budget: a $1 \times 1$ fire history reconstruction for the 20th century, Glob. Change Biol., 11, 398-420, doi:10.1111/j.13652486.2005.00920.x, 2006.

Mu, M., Randerson, J. T., van der Werf, G. R., Giglio, L., Kasibhatla, P., Morton, D., Collatz, G. J., DeFries, R. S., Hyer, E. J., Prins, E. M., Griffith, D. W. T., Wunch, D., Toon, G. C., Sherlock, V., and Wennberg, P. O.: Daily and 3-hourly variability in global fire emissions and consequences for atmospheric model predictions of carbon monoxide, J. Geosphys. Res., 116 D24303, doi:10.1029/2011JD016245, 2011.

Nachtergaele, F., van Velthuizen, H., Verekst, L., and Widberg, D.: Harmonized World Soil Database v 1.2., available at: http://webarchive.iiasa.ac.at/Research/LUC/ External-World-soil-database/HTML/ (last access: 31 October 2013), 2012.

Panagos, P.: The European soil database, GEO:Connexion, 5, 3233, 2006

Pereira, M., Trigo, R. M., da Camara, C. C., Pereira, J., and Leite, S. M.: Synoptic patterns associated with large summer forest fires in Portugal, Agr. Forest Meteorol., 129, 11-25, doi:10.1016/j.agrformet.2004.12.007, 2005.

R'Honi, Y., Clarisse, L., Clerbaux, C., Hurtmans, D., Duflot, V., Turquety, S., Ngadi, Y., and Coheur, P.-F.: Exceptional emissions of $\mathrm{NH}_{3}$ and $\mathrm{HCOOH}$ in the 2010 Russian wildfires, Atmos. Chem. Phys., 13, 4171-4181, doi:10.5194/acp-13-41712013, 2013.

Roberts, G., Wooster, M. J., Perry, G. L. W., Drake, N., Rebelo, L.M., and Dipotso, F.: Retrieval of biomass combustion rates and totals from fire radiative power observations: application to Southern Africa using geostationary SEVIRI imagery, J. Geophys. Res., 110, D21111, doi:10.1029/2005JD006018, 2005.

Roberts, G., Wooster, M. J., and Lagoudakis, E.: Annual and diurnal african biomass burning temporal dynamics, Biogeosciences, 6 , 849-866, doi:10.5194/bg-6-849-2009, 2009.

Rosa, I. M. D., Pereira, J. M. C., and Tarantola, S.: Atmospheric emissions from vegetation fires in Portugal (1990-2008): estimates, uncertainty analysis, and sensitivity analysis, Atmos. Chem. Phys., 11, 2625-2640, doi:10.5194/acp-11-2625-2011, 2011.

Roy, D. P., Boschetti, L., Justice, C. O., and Ju, J.: The collection 5 MODIS burned area product - global evaluation by comparison with the MODIS active fire product, Remote Sens. Environ., 112, 3690-3707, doi:10.1016/j.rse.2008.05.013, 2008.

Roy, D. P., Boschetti, L., and Smith, A. M.: Satellite remote sensing of fires, in: Oxford Handbook of Innovation, edited by: Belcher, C. M., Oxford University Press, Oxford, 77-93, 2013.

San-Miguel-Ayanz, J., Moreno, J. M., and Camia, A.: Analysis of large fires in European Mediterranean landscapes: lessons learned and perspectives, Forest Ecol. Manag., 294, 11-22, doi:10.1016/j.foreco.2012.10.050, 2013.

Schmuck, G., San-Miguel-Ayanz, J., Camia, A., Durrant, T., Boca, R., and Libertà, G.: Forest fires in Europe, Middle East and North Africa 2012, Tech. rep., Joint Research Center, Institute for Environment and Sustainability, Via Enrico Fermi 2749 , TP 261, 21027 Ispra (VA), Italy, doi:10.2788/58397, 2013 
Seiler, W. and Crutzen, P. J.: Estimates of gross and net fluxes of carbon between the biosphere and the atmosphere from biomass burning, Climatic Change, 2, 207-247, doi:10.1007/BF00137988, 1980 .

Sitch, S., Smith, B., Prentice, I. C., Arneth, A., Bondeau, A., Cramer, W., Kaplan, J. O., Levis, S., Lucht, W., Sykes, M. T., Thonicke, K., and Venevsky, S.: Evaluation of ecosystem dynamics, plant geography and terrestrial carbon cycling in the LPJ dynamic global vegetation model, Glob. Change Biol., 9, 161-185, doi:10.1046/j.1365-2486.2003.00569.x, 2003.

Sitch, S., Friedlingstein, P., Gruber, N., Jones, S. D., MurrayTortarolo, G., Ahlström, A., Doney, S. C., Graven, H., Heinze, C., Huntingford, C., Levis, S., Levy, P. E., Lomas, M., Poulter, B., Viovy, N., Zaehle, S., Zeng, N., Arneth, A., Bonan, G., Bopp, L., Canadell, J. G., Chevallier, F., Ciais, P., Ellis, R., Gloor, M., Peylin, P., Piao, S., Le Quéré, C., Smith, B., Zhu, Z., and Myneni, R.: Trends and drivers of regional sources and sinks of carbon dioxide over the past two decades, Biogeosciences Discuss., 10, 20113-20177, doi:10.5194/bgd-10-20113-2013, 2013.

Sofiev, M., Vankevich, R., Lotjonen, M., Prank, M., Petukhov, V., Ermakova, T., Koskinen, J., and Kukkonen, J.: An operational system for the assimilation of the satellite information on wildland fires for the needs of air quality modelling and forecasting, Atmos. Chem. Phys., 9, 6833-6847, doi:10.5194/acp-9-68332009, 2009.

Soja, A. J., Cofer, W. R., Shugart, H. H., Sukhinin, A. I., Stackhouse, P. W. J., McRae, D. J., and Conard, S. G.: Estimating fire emissions and disparities in boreal Siberia (1998-2002), J. Geophys. Res., 109, D14S06, doi:10.1029/2004JD004570, 2004.

Spracklen, D., Logan, J., Mickley, L., Park, R., Yevich, R., Westerling, A., and Jaffe, D.: Wildfires drive interannual variability of organic carbon aerosol in the Western US in summer, Geophys. Res. Lett., 34, L16816, doi:10.1029/2007GL030037, 2007.

Stohl, A., Berg, T., Burkhart, J. F., Fjæraa, A. M., Forster, C., Herber, A., Hov, Ø., Lunder, C., McMillan, W. W., Oltmans, S., Shiobara, M., Simpson, D., Solberg, S., Stebel, K., Ström, J., Tørseth, K., Treffeisen, R., Virkkunen, K., and Yttri, K. E.: Arctic smoke - record high air pollution levels in the European Arctic due to agricultural fires in Eastern Europe in spring 2006, Atmos. Chem. Phys., 7, 511-534, doi:10.5194/acp-7-511-2007, 2007.

Stroppiana, D., Brivio, P. A., Grégoire, J.-M., Liousse, C., Guillaume, B., Granier, C., Mieville, A., Chin, M., and Pétron, G.: Comparison of global inventories of $\mathrm{CO}$ emissions from biomass burning derived from remotely sensed data, Atmos. Chem. Phys., 10, 12173-12189, doi:10.5194/acp-10-12173-2010, 2010.

Szopa, S., Hauglustaine, D. A., and Ciais, P.: Relative contributions of biomass burning emissions and atmospheric transport to carbon monoxide interannual variability, Geophys. Res. Lett., 34, L18810, doi:10.1029/2007GL030231, 2007.

Tosca, M. G., Randerson, J. T., and Zender, C. S.: Global impact of smoke aerosols from landscape fires on climate and the Hadley circulation, Atmos. Chem. Phys., 13, 5227-5241, doi:10.5194/acp-13-5227-2013, 2013.

Turetsky, M., Kane, E. S., Harden, J. W., Ottmar, R. D., Manies, K. L., Hoy, E., and Kasischke, E. S.: Recent acceleration of biomass burning and carbon losses in Alaskan forests and peatlands, Nat. Geosci., 4, 27-31, doi:10.1038/ngeo1027, 2011.
Turetsky, M. R., Donahue, W., and Benscoter, B. W.: Experimental drying intensifies burning and carbon losses in a northern peatland, Nature Communications, 2, 514, doi:10.1038/ncomms1523, 2011.

Turquety, S.: The atmospheric impact of wildfires, in: Oxford Handbook of Innovation, edited by: Belcher, C. M., Oxford University Press, Oxford, 2013.

Turquety, S., Logan, J., Jacob, D., Hudman, R., Leung, F., Heald, C., Yantosca, R., Wu, S., Emmons, L., Edwards, D., and Sachse, G.: Inventory of boreal fire emissions for North America in 2004: the importance of peat burning and pyro-convective injection, J. Geophys. Res., 112, D12S03, doi:10.1029/2006JD007281, 2007.

Turquety, S., Hurtmans, D., Hadji-Lazaro, J., Coheur, P.-F., Clerbaux, C., Josset, D., and Tsamalis, C.: Tracking the emission and transport of pollution from wildfires using the IASI CO retrievals: analysis of the summer 2007 Greek fires, Atmos. Chem. Phys., 9, 4897-4913, doi:10.5194/acp-9-4897-2009, 2009.

Urbanski, S. P.: Combustion efficiency and emission factors for wildfire-season fires in mixed conifer forests of the northern Rocky Mountains, US, Atmos. Chem. Phys., 13, 7241-7262, doi:10.5194/acp-13-7241-2013, 2013.

Urbanski, S. P., Hao, W. M., and Nordgren, B.: The wildland fire emission inventory: western United States emission estimates and an evaluation of uncertainty, Atmos. Chem. Phys., 11, 12973-13000, doi:10.5194/acp-11-12973-2011, 2011.

van der Werf, G. R., Randerson, J. T., Giglio, L., Collatz, G. J., Kasibhatla, P. S., and Arellano Jr., A. F.: Interannual variability in global biomass burning emissions from 1997 to 2004, Atmos. Chem. Phys., 6, 3423-3441, doi:10.5194/acp-6-3423-2006, 2006.

van der Werf, G. R., Randerson, J. T., Giglio, L., Collatz, G. J., Mu, M., Kasibhatla, P. S., Morton, D. C., DeFries, R. S., Jin, Y., and van Leeuwen, T. T.: Global fire emissions and the contribution of deforestation, savanna, forest, agricultural, and peat fires (1997-2009), Atmos. Chem. Phys., 10, 11707-11735, doi:10.5194/acp-10-11707-2010, 2010.

Vestreng, V., Mareckova, K., Kakareka, S., Malchykhina, A., and Kukharchyk, T.: Inventory Review 2007; Emission Data reported to LRTAP Convention and NEC Directive, MSC-W Technical Report 1, Tech. rep., EMEP/MSC-W, Oslo, Norway, 2007.

Wiedinmyer, C., Akagi, S. K., Yokelson, R. J., Emmons, L. K., AlSaadi, J. A., Orlando, J. J., and Soja, A. J.: The Fire INventory from NCAR (FINN): a high resolution global model to estimate the emissions from open burning, Geosci. Model Dev., 4, 625641, doi:10.5194/gmd-4-625-2011, 2011.

Wooster, M., Roberts, G., Perry, G., and Kaufman, Y.: Retrieval of biomass combustion rates and totals from fire radiative power observations: calibration relationships between biomass consumption and fire radiative energy release, J. Geophys. Res., 110, D14311, doi:10.1029/2005JD006318, 2005.

Zobler, L.: A World Soil File for Global Climate Modelling. NASA Technical Memorandum 87802, Tech. rep., NASA Goddard Institute for Space Studies, New York, New York, USA, 1986. 